\title{
Ankylosing Spondylitis: From Cells to Genes
}

\author{
José Francisco Zambrano-Zaragoza, Juan Manuel Agraz-Cibrian, \\ Christian González-Reyes, Ma. de Jesús Durán-Avelar, and Norberto Vibanco-Pérez
}

Universidad Autónoma de Nayarit, Unidad Académica de Ciencias Químico Biológicas y Farmacéuticas, CP. 63190 Tepic Nay., Mexico

Correspondence should be addressed to José Francisco Zambrano-Zaragoza; jzambran44@gmail.com

Received 26 March 2013; Revised 19 June 2013; Accepted 19 June 2013

Academic Editor: Madhav Bhatia

Copyright @ 2013 José Francisco Zambrano-Zaragoza et al. This is an open access article distributed under the Creative Commons Attribution License, which permits unrestricted use, distribution, and reproduction in any medium, provided the original work is properly cited.

\begin{abstract}
Ankylosing spondylitis (AS) is a chronic inflammatory disease of unknown etiology, though it is considered an autoimmune disease. HLA-B27 is the risk factor most often associated with AS, and although the mechanism of involvement is unclear, the subtypes and other features of the relationship between HLA-B27 and AS have been studied for years. Additionally, the key role of IL-17 and Th17 cells in autoimmunity and inflammation suggests that the latter and the cytokines involved in their generation could play a role in the pathogenesis of this disease. Recent studies have described the sources of IL-17 and IL-23, as well as the characterization of Th17 cells in autoimmune diseases. Other cells, such as NK and regulatory T cells, have been implicated in autoimmunity and have been evaluated to ascertain their possible role in AS. Moreover, several polymorphisms, mutations and deletions in the regulatory proteins, protein-coding regions, and promoter regions of different genes involved in immune responses have been discovered and evaluated for possible genetic linkages to AS. In this review, we analyze the features of HLA-B27 and the suggested mechanisms of its involvement in AS while also focusing on the characterization of the immune response and the identification of genes associated with AS.
\end{abstract}

\section{Introduction}

The spondyloarthropathies (SpA), now better denominated as spondyloarthritides (SpAs), are a diverse group of interrelated inflammatory arthritides that share multiple clinical features and common genetic predisposing factors. This group includes not only the prototypical disease, ankylosing spondylitis (AS), but also reactive arthritis (ReA), psoriatic arthritis (PsA), Crohn's disease, undifferentiated SpA, and juvenile-onset spondyloarthritis [1].

The clinical features of AS include inflammatory back pain, asymmetrical peripheral oligoarthritis, enthesitis, and specific organ involvement, such as anterior uveitis, psoriasis, and chronic inflammatory bowel disease [2]. Its major clinical features include sacroilitis, loss of spinal mobility, and spinal inflammation. Chronic inflammation leads to fibrosis and ossification, where bridging spurs of bone known as syndesmophytes form, especially at the edges of the intervertebral discs, producing the ankylosing [3].
AS affects men more often than women, at a ratio of $2: 1$ [4]. The prevalence of the disease is between 0.1 and $1.4 \%$ of general populations [2]. Studies conducted in different countries have shown that the incidence of AS varies from 0.5 to 14 per 100,000 people per year [2]. Diagnoses of AS are based more on clinical features than on laboratory tests; currently, diagnoses are made in accordance with the modified New York criteria (Table 1) [5].

AS is of unknown etiology but is considered an autoimmune disease that involves environmental and genetic factors. It is known to be highly heritable, as $>90 \%$ of the risk of developing the disease has been shown to be genetically determined [6]. As in the case of most common heritable diseases, progress in identifying candidate genes associated with the disease, and their possible role in pathogenesis, is one of the challenges that must be confronted in the near future.

This review discusses recent advances in HLA-B27 studies, characterization of immune responses, and the identification of some genes associated with AS. 
TABLE 1: Modified New York criteria 1984 for ankylosing spondylitis [5].

\section{Clinical criteria \\ (i) Low back pain and stiffness for longer than 3 months, which improve with exercise but are not relieved by rest. \\ (ii) Limitation of motion of the lumbar spine in both the sagittal and frontal planes. \\ (iii) Limitation of chest expansion relative to normal values correlated for age and sex.}

Radiological criterion

Sacroilitis grade $\geq 2$ bilateral, or grade 3-4 unilateral.

For definite ankylosing spondylitis the radiological criterion and at least one clinical criterion must be satisfied.

\section{HLA-B27}

Human leukocyte antigen (HLA)-B27 is a Major Histocompatibility Complex (MHC) Class I molecule that is encoded on chromosome $6 \mathrm{p}$. It is ubiquitous among cell types and is highly expressed on antigen-presenting cells. After translation and tertiary folding, HLA-B27 heavy chains form heterotrimeric complexes with $\beta 2$-microglobulin $(\beta 2 \mathrm{~m})$ and intracellular peptides derived from self-proteins, viruses, and bacteria. The association of HLA-B27 with AS was first described for HLA alleles and inflammatory diseases in 1973, and this association remains one of the best examples of a disease association with a hereditary marker [7, 8]; however, it does not explain the cause of the disease. Reports indicate that the risk of developing AS is approximately 5\% in HLAB27-positive subjects, but substantially higher for HLA-B27positive relatives [9]. More than $90 \%$ of Caucasians with AS are HLA-B27-positive; however, most HLA-B27-positive individuals remain healthy, suggesting that other genes, both inside and outside the $M H C$, are involved in disease susceptibility [10-12]. Thus, HLA-B27 may only account for perhaps 20 to $50 \%$ of overall genetic susceptibility to AS $[13,14]$.

Though there is no question that $H L A-B 27$ is the major susceptibility gene for AS, its mechanism of action remains unknown. There is strong evidence that different subtypes of HLA-B27 have distinct strengths of association with AS in specific populations. Some 100 HLA-B27 subtypes have been reported to date (http://hla.alleles.org/proteins/class1.html), but the number is increasing rapidly. Most of them differ from each other by only a few amino acids, but these changes are sufficient to alter the molecule's peptide-binding properties. HLA-B ${ }^{*} 2705$ is present in all populations and appears to be the original or "parent" HLA-B27 molecule. Most of the other subtypes appear to have evolved along three pathways, defined by the pattern of amino acid substitutions in the first $(\alpha 1)$ and second $(\alpha 2)$ domains and through geographic patterns $[15,16]$. The most common subtypes reported in association with AS are HLA-B* $2705, B^{*} 2702, B^{*} 2704$, and $B^{*} 2707$ [17-19]; whereas HLA-B* 2706 and $B^{*} 2709$, which are common in Southeast Asia and Sardinia, have no association with AS, possibly due to amino acid differences in the B pocket of the HLA antigen-binding cleft that could modify the composition of the peptides that these HLA-B27 subtypes present $[15,20]$. HLA-B 2706 and $B^{*} 2709$ differ from the AS-associated subtypes at residue 116 in the second domain. HLA-B* 2706 differs from HLA-B* 2704, which is highly disease-associated among the Chinese, in only two amino acid positions (H114D, D116Y), both of which reside on the floor of the $\mathrm{F}$ pocket of the peptide-binding groove. HLA-B ${ }^{*} 2709$, meanwhile, differs from B*2705 by a single amino acid substitution at position 116 (D116H) [21, 22]. This position is a relevant polymorphism that gives rise to different repertoires of bound peptides and cytotoxic $\mathrm{CD} 8^{+}$ T cells (CTL). As an example, pVIPR, a self-peptide derived from type I receptor of vasoactive intestinal peptide evokes autoreactive CTL responses in HLA-B*2705 individuals, mostly patients with AS, but not in HLA-B*2709 healthy individuals [23].

Several theories have been proposed to explain the molecular pathogenic role of HLA-B27 in AS, including the presentation of arthritogenic peptides, the aberrant folding of surface heavy chains, HLA-B27 misfolding, and enhanced intracellular microbial survival (Figure 1).

The dominant paradigm (arthritogenic peptide hypothesis) has been that self-peptides displayed by folded HLAB27 become the target of autoreactive $\mathrm{CD}^{+} \mathrm{T}$ cells because they resemble microbial peptides, which does not occur with other HLA molecules. These T cells then cause cytotoxicity resulting in chronic inflammation. This hypothesis invokes the unique peptide-binding specificity of HLA-B27 as the problem. In support of this concept, HLA-B27-restricted $\mathrm{CD}^{+}$T-cell clones with specificity for bacteria or possibly self-peptides have been detected in both synovial fluid and peripheral blood of patients with ReA and AS [24]. Additionally, the finding of a self-peptide derived from the vasoactive intestinal peptide receptor (VIPR) that shows high sequence homology to an Epstein-Barr virus derived epitope of latent membrane protein 2 (pLMP2) peptide were reported in patients with AS. Although the VIPR peptide was chosen as a potential target that exhibit HLA-B27 subtype-dependent molecular mimicry with the EBV epitope, there was little cross-reactivity between VIPR and EBV-specific CD8 ${ }^{+} \mathrm{T}$ cells [25], but as yet there is no proof of the involvement of these peptides in the pathogenesis of AS.

The cell surface HLA-B27 homodimers hypothesis suggests that HLA-B27 heavy chain homodimers are produced on the cell surface during endosomal recycling [26]. The formation of disulphide bonds between the cysteine residue at position $67\left(\mathrm{C}_{67}\right)$ in the $\mathrm{B}$ pockets of the peptide binding groove of two separate heavy chain molecules creates homodimers with no participation by $\beta 2 \mathrm{~m}$. HLA-B27 homodimers bind to specific receptors expressed on NK cells, T lymphocytes, and myelomonocytic cells; therefore, they could play a role in the pathogenesis of autoimmune disorders [27-29]. In support of this theory, it was found that HLA-B27 positive patients showed an increased number of NK cells and CD ${ }^{+}$ T cells expressing KIR3DL2, a killer immunoglobulin-like receptor (KIR) that recognizes homodimers of HLA-B27 but not its heterodimers [29]. However, residue $C_{67}$, which is critical for the formation of homodimers, exists in both HLAB27 subtypes those that are related to AS and those that are 


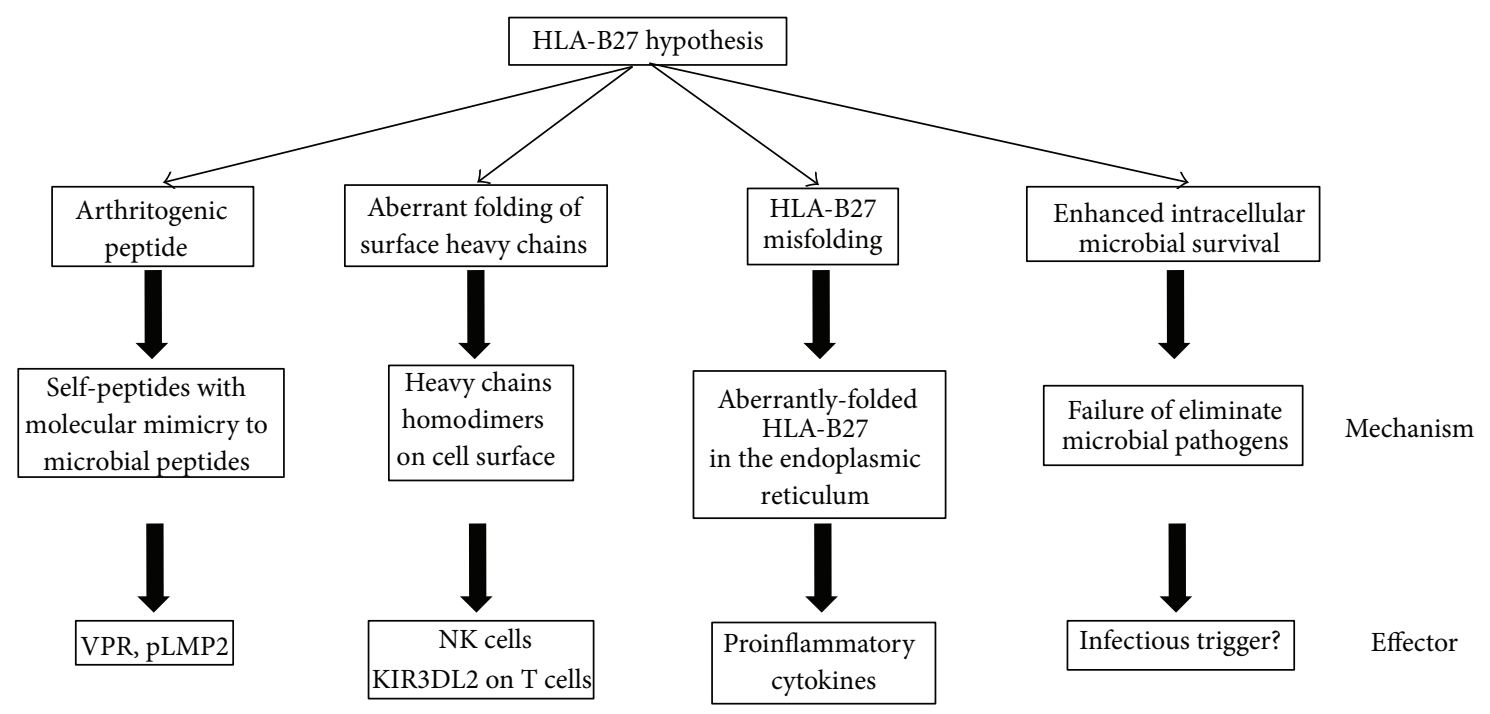

FIgURE 1: Proposed theories to explain the molecular pathogenic role of HLA-B27 in AS.

not [30]. As counter arguments, no association has yet been reported between free heavy chains of HLA-B27 molecules and predisposition to AS [31], and the HLA-B2706 subtype, which is not related to AS, also forms homodimers [32].

The HLA-B27 misfolding hypothesis proposes that AS results from an accumulation of aberrantly-folded HLAB27 in the endoplasmic reticulum (ER), that produces an inflammatory response [33]. ER stress resulting from the accumulation of misfolded heavy chains then activates the unfolded protein response (UPR), triggering a series of signaling pathways that culminate in the induction of ERresident chaperones $(\mathrm{BiP})$, which may induce cytokine production by macrophages, thereby promoting inflammation $[34,35]$. Another pathway that can activate ER stress is the ER-overload response (EOR) to excessive membrane protein trafficking within the ER, which involves activation of the transcription of nuclear factor kappa $B(N F-\kappa B)$ that can stimulate the synthesis of proinflammatory cytokines such as TNF- $\alpha$, IL-1 and IL-6 in certain cell types [36].

The enhanced intracellular microbial survival hypothesis may also play a role in the pathogenesis of AS. This mechanism is based on the inability of HLA-B27-positive individuals to eliminate certain intracellular pathogens. Abnormal immune system activation or modulation can occur due to ineffective peptide loading into HLA-B27, leading to excessive viral or intracellular bacterial proliferation and delayed antigenic peptide clearance. Carriers of HLA-B27 are defective in the killing of intracellular bacterial species of the genera Yersinia, Salmonella, Shigella, and Chlamydia [37, 38], all of which - as is well documented - are involved in the triggering of reactive arthritis [39]; however, an infectious trigger for AS has yet to be demonstrated.

It is highly likely that all of these mechanisms play some part in predisposing an individual to AS. Unfortunately, the precise role of HLA-B27 in pathogenesis remains unclear, but features that distinguish it from other genes and differences among its many subtypes have provided the basis for several putative explanations as to how it might predispose individuals to AS and mediate the disease.

\section{Cells and AS}

3.1. Th17 Cells. Interleukin 17 (IL-17) is a proinflammatory cytokine that contributes to the pathogenesis of several inflammatory diseases. One major source of IL-17 is a lineage of $\mathrm{T}$ cells known as T helper 17 cells (Th17 cells), but $\mathrm{T}$ cells, natural killer (NK) cells, mast cells, and neutrophils may also be involved [40]. It is well established that IL-17 activity contributes to various aspects of acute inflammation, because it mediates the release of IL- 6 and IL-8 (Figure 2). The role of IL-17 in rheumatic diseases has been ascertained on the basis of findings that indicate that IL-17 promotes cartilage damage in a murine model [40].

It is also well known that IL-23 is able to induce IL17 production and, therefore, is a crucial factor in the Th17 response [41]. In this regard, recent studies suggest that IL23R could be one of the major genetic factors involved in susceptibility to AS [42]. Moreover, Th17 cells have been implicated in many experimental autoimmune diseases [41], and in the pathogenesis of several inflammatory diseases, including rheumatoid arthritis (RA) [43], psoriasis [44], and inflammatory bowel disease [45]. They also stimulate the formation of osteoclasts and, consequently, bone resorption and the recruitment of neutrophils and monocytes [46].

Several studies have been carried out in efforts to determine the role of different immune cells in the pathogenesis of AS, as well as $\mathrm{CD} 4^{+} \mathrm{T}$ cells producing IL-17 that have been associated with autoimmune diseases [47], particularly with inflammatory autoimmune diseases [48]. Mast cells infiltrated into synovial joints in SpAs have increased the expression of IL-17, which supports the notion that they could be a source of Th17 generation [49]. Moreover, Th17 cells have been shown to be involved in promoting the inflammatory process in AS [43]. Significantly elevated levels 


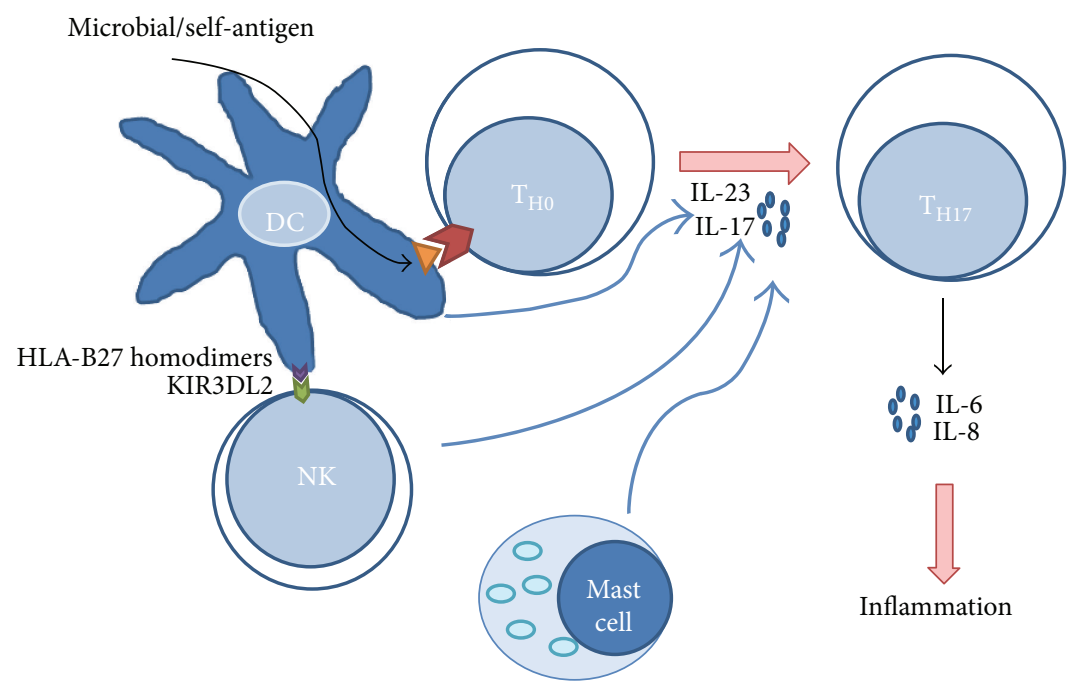

Figure 2: Possible role of Th17 in AS: dendritic cells (DC) could present an arthritogenic peptide derived from microbial pathogens or selfantigens to $\mathrm{T}_{\mathrm{H} 0}$ cells. The differentiation of these $\mathrm{T}$ cells could be influenced by IL-17 secreted by NK cells that recognize HLA-B27 homodimers and mast cells to induce the differentiation to $\mathrm{T}_{\mathrm{H} 17}$ cells that are involved in inflammation by molecules secreted, such as IL- 6 and IL-8.

of Th17 cells have been reported in the peripheral blood of patients with AS [46, 50-52], suggesting that they could have a role in inflammation. Moreover, IL-17 and IL-23 have been found to be high as well in the serum of AS patients $[42,53,54]$. The role of Th17 cells in inflammation, and in AS, is supported by studies that have demonstrated that anti-TNF- $\alpha$ therapy reduces levels of IL-17 [51] and Th17 cells in patients with AS [46]. Though it is assumed that inflammation stimulates new bone formation, no concrete correlation between inflammation and osteoproliferation has yet been demonstrated [55]; moreover, inflammation and new bone formation can occur at distinct locations [56] and, apparently, anti-TNF- $\alpha$ therapy does not affect new bone formation in AS [57, 58]. Despite the fact that the relationship between inflammation and new bone formation remains controversial, there is a clear relationship between AS, Th17 cell levels, and the latter's cytokine secretion, which suggests an important role in the inflammatory process observed in AS (Figure 2).

3.2. Regulatory $T$ Cells. Regulatory $\mathrm{T}$ cells (Tregs) mediate peripheral tolerance by actively suppressing effector $\mathrm{T}$ cells and inhibiting immune-mediated tissue damage. Tregs were first identified by the expression of CD25, but now they are characterized by the expression of the intracellular transcription factor, FoxP3 [59]. Tregs function by maintaining immune tolerance and preventing inflammatory diseases. In addition, they have been implicated in the regulation of almost every adaptive immune response and, therefore, also in inflammatory responses, by using appropriated mechanisms that inhibit targeted cell populations [60].

In the case of AS, few studies have been carried out to analyze the levels of Tregs in the peripheral blood of patients; however, low percentages of Treg cells have been reported in the peripheral blood $[46,51,69,70]$, and in the synovial fluid [71] of patients with AS, suggesting an imbalance between
Tregs and the adaptive immune response. Moreover, AS patients treated with anti-TNF therapy showed similar levels of Treg cells to those observed in healthy subjects [46]. These data suggest a possible role of Tregs in AS, and Th17/Tregs imbalance has been proposed as playing a novel role in AS [69].

3.3. NK Cells. The recognition that both the adaptive and innate immune responses play key roles in AS led us to focus on NK cells as a target for improving our understanding of the pathogenesis of AS. NK cells are major components of innate immunity and provide surveillance during early defense against virus, intracellular bacteria, and cancer cells [72], but they have also been associated with autoimmunity. NK cells can be identified by the expression of CD56 and the lack of the CD3 complex [73]. Decreased numbers and impaired function of peripheral blood NK cells in patients with autoimmune diseases such as systemic lupus erythematosus (SLE), multiple sclerosis, diabetes, RA, and psoriasis have been reported [74-78]. However, the frequencies of circulating $\mathrm{CD}^{-} \mathrm{CD}^{-} 6^{+} \mathrm{NK}$ cells have been reported to be higher in AS patients [73, 79], as have those of the CD56 ${ }^{\text {dim }} \mathrm{CD} 16^{+}$subsets, but not $\mathrm{CD} 56^{\text {bright }} \mathrm{CD} 16^{+}[80]$. The role of NK cells in AS has been supported by the finding that the HLA-B27 protein is specifically recognized by the NK-inhibitory receptor KIR3DL1 [73]. The killing activity of NK cells is balanced by the signals transduced by both inhibitory and activating receptors [73]. Surface receptors of NK cells have been evaluated in several studies, and NKp $44^{+}$ and $\mathrm{NKp} 46^{+}$receptors have been evaluated in patients with AS, while NKp44 expression has been found to be elevated in the ileum of patients with AS. Also, these cells secreted increased amounts of IL-22 [73, 81]. Indeed, healthy HLAB27-positive subjects have similar NK cell levels to those in AS patients. Increasing evidence points to a role of the KIRs 
TABLE 2: Association studies between CTLA4 +49-A/G and PD1 polymorphisms with ankylosing spondylitis.

\begin{tabular}{|c|c|c|c|c|c|c|}
\hline Gene & Population & Year & Study type & SNP & Association & Reference \\
\hline \multirow{3}{*}{ CTLA4 } & Iranian & 2010 & Case control & \multirow{3}{*}{$\begin{array}{l}+49-\mathrm{A} / \mathrm{G} \\
(\mathrm{rs} 2317754)\end{array}$} & NS & {$[61]$} \\
\hline & European & 2001 & Case control & & NS & {$[62]$} \\
\hline & Taiwanese & 2010 & Case control & & NS & [63] \\
\hline \multirow{5}{*}{ PD1 } & $\begin{array}{c}\text { Han } \\
\text { Chinese }\end{array}$ & 2009 & Case control & $\begin{array}{l}\text { PD1.3, } \\
\text { PD1.5, } \\
\text { PD1.9 }\end{array}$ & $\begin{array}{c}\text { NS } \\
\text { NS } \\
\text { Risk }\end{array}$ & {$[64]$} \\
\hline & Iranian & 2011 & Case control & $\begin{array}{l}\text { PD1.3, } \\
\text { PD1.9 }\end{array}$ & $\begin{array}{l}\text { NS } \\
\text { NS }\end{array}$ & {$[65]$} \\
\hline & Taiwanese & 2011 & Case control & PD1.1 & Risk & {$[66]$} \\
\hline & Korean & 2006 & Case control & $\begin{array}{l}\text { PD1.5, } \\
\text { PD1.9 }\end{array}$ & $\begin{array}{c}\text { NS } \\
\text { Risk }\end{array}$ & {$[67]$} \\
\hline & Chinese & 2011 & Case control & PD1.9 & Risk & {$[68]$} \\
\hline
\end{tabular}

PD1.1 (rs36084323), PD1.3 (rs11568821), PD1.5 (rs2227981), and PD1.9 (rs2227982).

NS: not significant.

in the development of autoimmune diseases. In particular, a positive association of KIR3DS1 (an activating receptor) and a negative association of KIR3DL1 (an inhibitory receptor) with AS have been reported [82]. Additionally, it is known that KIR3DL2 binds to free H chain forms of HLA-B27 [83]. Genetic polymorphisms of KIRs genes have been studied by some groups, finding that KIR2DL1, KIR2DL5, KIR2DS5, KIR3DS1, and KIR3DL1 are all associated with AS, though in different populations $[82,84-91]$. These data suggest that NK cells could play a relevant pathogenic role in AS via the expression of KIRs [92].

\section{Molecules, Their Genes and AS}

4.1. CCR6. The chemokine (C-C motif) receptor 6 (CCR6) is expressed on $\mathrm{B}$ cells, a fraction of $\mathrm{T}$ cells, and immature DCs, and studies have shown that it is a specific marker for Th17 cells that distinguishes them from other helper $\mathrm{T}$ cells. Moreover, CCR6 has been shown to be important for B-lineage maturation and antigen-driven B-cell differentiation and may regulate the migration and recruitment of dendritic cells (DCs) and T cells during inflammatory and immunological responses. $\mathrm{CCR}^{+}$human memory $\mathrm{T}$ cells have a low stimulation threshold for IL-10 production and, consequently, secrete IL-10 after suboptimal stimulation by autologous DCs [93].

CCR6 is considered an important receptor that guides effector T cells into inflamed tissue, thus favoring the Th17 phenotype and downregulating the Tregs. Thus, CCR6 ${ }^{+} \mathrm{T}$ cells play a central role in balancing regulatory and inflammatory processes during homeostasis and inflammation [94]. It has also been reported that $\mathrm{CCR} 6^{-}$deficient mice have altered $\mathrm{CD}^{+}{ }^{+} \mathrm{T}$-cell responses, including reduced hypersensitivity and enhanced delayed type hypersensitivity responses [95], all of which supports the role of CCR6 in homeostasis.

CCR6 are also involved in several autoimmune diseases, including psoriasis and RA [96-98]; however, CCR6 polymorphisms have not been associated with AS in the few populations that have been analyzed $[98,99]$, despite the fact that some studies have demonstrated that it is expressed on the Th17 cells of AS patients $[100,101]$ and that these patients have a higher proportion of these cells [43].

4.2. Negative Costimulatory Molecules: CTLA-4 and PD-1. Cytotoxic T-lymphocyte antigen 4 (CTLA-4, CD154) is a costimulatory molecule that is expressed by activated $\mathrm{T}$ cells and interacts with the B7 molecules on the surface of antigenpresenting cells to induce downregulation of T-cell activation. CTLA-4, which is encoded by the CTLA4 gene located on chromosome 2 p33, is a structural homologue of CD28 [61]. Engagement of CTLA-4 appears to regulate ongoing Tcell responses and induce peripheral T-cell tolerance, while the absence of this function appears to be involved in autoimmunity [102]. In addition, CTLA-4 is highly expressed by regulatory $\mathrm{T}$ cells and could play an important role in their functioning [103]. Theoretically, polymorphisms of CTLA4 that reduce CTLA-4 expression may cause autoimmune Tcell clonal proliferation, thus contributing to the pathogenesis of autoimmune diseases [61]. The CTLA4 gene has many single nucleotide polymorphisms (SNP), some of which are present in regulatory positions, while others appear in $3^{\prime}$ UTR, but the most important one is the leader sequence (+49 A/G; rs231775) $[62,104,105]$. The $+49-\mathrm{A} / \mathrm{G}$ is located at position +49 of the first exon of the CTLA4 gene, where it provokes a threonine-to-alanine change in amino acid 17 of the leader peptide [103]. It has been reported that +49 A/G polymorphism in CTLA4 gene alters the intracellular distribution of CTLA-4, IL-2 production, and T-cell proliferation $[103,106]$, suggesting their possible role in autoimmune diseases. This SNP have been analyzed in patients with AS in different populations (Table 2), but so far results are negative [61-63], though higher levels of circulating CTLA4 in SpAs [107] and association of the +49-GG genotype with circulatory C-reactive protein in patients with AS [63] have been found, indicating a possible role in the pathogenesis of AS.

The programmed cell death-1 (PDCD1, also known as $P D 1)$ gene is one of the costimulatory genes located on 
chromosome 2q37.3. It encodes the surface receptor PD-1, an inhibitory immunoreceptor expressed on activated $\mathrm{T}$ cells, $\mathrm{B}$ cells, and myeloid cells belonging to the immunoglobulin superfamily B7-CD28 [108]. PD-1 is expressed in a variety of hematopoietic cells on the periphery after stimulation by antigen receptor signaling and cytokine receptors. Two PD-1 ligands have been described (PD-L1 and PD-L2), and their expression is regulated by the inflammatory environment, cytokines such as TNF- $\alpha$, type 1 and 2 interferons, IL-2, IL7, and IL-15 [59].

The co-stimulatory pathways consisting of the PD-1 receptor and its ligands deliver inhibitory signals that regulate the balance among T-cell activation, tolerance, and immune-mediated tissue damage [59]. Various SNPs in the PD1 gene have been identified, such as PD1.1 (rs36084323), PD1.3 (rs11568821), PD1.5 (rs2227981), and PD1.9 (rs2227982). Among these, PD1.3, PD1.5, and PD1.9 have been associated with autoimmune disorders in different ethnic groups [134]. In the case of AS, despite controversies among studies of the polymorphism associated with the disease, it appears that PD1.3, PD1.5, and PD1.9 are all candidates for association (Table 2) [64-68]. However, it is necessary to study these polymorphisms or conduct meta-analysis in additional populations, before these associations can be confirmed.

4.3. Endoplasmic Reticulum Aminopeptidase 1 (ERAP1). ERAP1 is the term currently accepted by the human genome organization (HUGO) nomenclature committee (HGNC), though in the past it was known by such names as endoplasmic reticulum aminopeptidase associated with antigen processing (ERAAP), adipocyte-derived leucine aminopeptidase (A-LAP), and aminopeptidase regulating tumor necrosis factor receptor I (TNFRI) shedding (ARTS-1). ERAP1 is a zinc aminopeptidase belonging to the M1 family of the metallopeptidases that share the consensus GAMEN and $\operatorname{HEXXH}(\mathrm{X}) 18 \mathrm{E}$ zinc-binding motifs [135]. Two major ERAP1 protein isoforms are generated: the longer isoform, a (ERAP1- $a$ ) and the shorter isoform, b (ERAP1- $b$ ). It has been reported that the isoform ERAP1- $b$ is more abundant than ERAP1- $a$ [136]. Because ERAP1 is highly polymorphic multiple splice variants with potential effects on biological functions have been described, for example, rs2287987 (M349V) located on the active site, rs17482078 (R725Q), and rs27044 (Q730E), which are exposed on the inner surface of the C-terminal cavity and could affect the substrate sequence or length specificity. Other polymorphisms, such as rs26653 (R127P), rs30187 (K528R), and rs10050860 (D575N), localized at domain junctions, reduce either specificity or aminopeptidase activity toward a synthetic peptide substrate by altering the conformational change between open and closed conformations [137].

The association of ERAP1 SNPs with AS can be explained from a functional perspective. The protein ERAP1 has three known biological functions. First, in the endoplasmic reticulum, ERAP1 acts as a molecular ruler, trimming peptide antigens to optimal length for binding to MHC class I molecules [138]. Complex proteins are initially degraded in the cytosol by the proteasome complex to generate peptide fragments up to 25 amino acids in length [139]. These antigenic peptides, and their N-terminal extended precursors, are subsequently transported into the ER by the transporter associated with antigen processing (TAP) that preferentially transports peptides of 8-16 residues in length [140-142]. Nascent MHC class I molecules typically bind short peptide fragments 8-9 residues long and transport them to the cell surface for presentation to T cells. ERAP1 is expressed in the lumen of the ER, where peptide loading to MHC class I molecules takes place. Here, ERAP1 preferentially trims substrates 10-16 residues in length; whereas peptides 8-9 residues in length are optimal for binding MHC class I molecules $[143,144]$. Second, the cleavage of cell surface receptors by proinflammatory cytokines such as TNFR1 [145], IL-1R2 [146], and IL-6R $\alpha$ [147] results in the downregulation of their intracellular signaling. For this reason, the malfunctioning of ERAP1 would lead to either an increase or decrease in the number of cell surface receptors available for these cytokines, thus propitiating proinflammatory effects and, finally, raising disease susceptibility to AS, though some polymorphisms of ERAP1 associated with AS do not influence the cytokine receptor levels in patients with this disease [148]. Third, ERAP1 is involved in the activation of macrophages induced by lipopolysaccharide (LPS) and interferon (IFN) $-\gamma$ [149].

The first confirmed association of ERAP1 with AS was reported by the Wellcome Trust Case-Control Consortium and Australo-Anglo-American Spondyloarthritis Consortium (WTCCC/TASC) in 2007. They used 14,500 nonsynonymous SNPs to discover the ERAP1 association in AS. This was the first non-MHC gene for which a definitive AS-association was observed [109]. In that study, the minor allele frequency of the ERAP1 SNP rs30187 and rs27044 in AS patients was considerably higher than in controls, and those variants have been repeatedly confirmed by nearly all population studies as conferring strong susceptibility to this disease. At the same time, this study indicates that in the $M H C$ locus $H L A-B 27$ confers the greatest risk of AS susceptibility, with an attributable risk of 50\%; ERAP1 is the second strongest association, with an attributable risk of 26\% [109]. Recent genome-wide association studies (GWAS) have revealed numerous ERAP1 polymorphisms that are associated with AS and strongly related to the $H L A-B 27$ MHC I allele [110, 150]. One GWAS study found that the polymorphisms of ERAP1 only affect AS risk in HLA-B27-positive individuals [111]. The association of AS with ERAP1 has been replicated in multiple cohorts and ethnicities, including a family-based association study [112], case-control studies [113-123], and meta-analyses [124, 125] of Canadian, British, Portuguese, Chinese, Hungarian, Korean, Spanish, and Iranian populations. Those studies were able to replicate the association of the rs30187 and rs27044 SNP in all the aforementioned populations, with the sole exception of Pazar's study, where the SNP rs30187 failed to show any significant connection with AS susceptibility [117]. It is important to mention that the North American Spondylitis Consortium (NASC) studied multiplex AS families, finding and reporting, for the first time, a novel haplotype ERAP2 associated with AS [112]. In several disease models, the association of ERAP1 with AS in HLA-B27-positive cases is consistent. There, aberrant 
trimming of peptides or the presentation of ERAP1 and HLAB27 are involved in the pathogenesis of HLA-B27-associated AS. These findings suggest that ERAP1 participates in AS pathogenesis with associated alleles that reduce the risk of disease through a mechanism that involves altered peptide presentation by MHC class I, though a great deal of additional experimental research is necessary to validate this. In Table 3, studies of association of ERAP1 and AS are summarized.

4.4. Receptor for the Fc Fragment of $\operatorname{IgG}(F c \gamma R)$. Receptors for the $\mathrm{Fc}$ fragment of $\operatorname{IgG}(\mathrm{Fc} \gamma \mathrm{R})$ form a group of type I transmembrane glycoproteins belonging to the Ig superfamily and expressed mostly on leucocytes, providing a critical link between the humoral and cellular arms of the immune response. $\mathrm{Fc} \gamma \mathrm{R}$ has three major functions: (1) positive and negative regulation of cell activation; (2) Ig transport and regulation of Ig homeostasis; and (3) uptake of the immune complex (IC) for the degradation and promotion of antigenic peptides for antigen presentation $[151,152]$ that can trigger effector mechanisms, such as antibody-dependent cellular cytotoxicity (ADCC), phagocytosis, degranulation, and cytokine production via immune tyrosine activating or inhibitory motifs (ITAM or ITIM). Three classes of leukocyte $\mathrm{Fc} \gamma \mathrm{R}$ are currently distinguished: $\mathrm{Fc} \gamma \mathrm{RI}$ (CD64), $\mathrm{Fc} \gamma \mathrm{RII}(\mathrm{CD} 32)$, and Fc $\gamma$ RIII (CD16). Fc $\gamma$ RI is a high-affinity receptor that binds both monomeric IgG and immune complexes; whereas the affinity of IgG is low for Fc $\gamma$ RII and intermediate for Fc $\gamma$ RIII [153]. Fc $\gamma$ RIa, Fc $\gamma$ RIIa, Fc $\gamma$ RIIc, and $\mathrm{Fc} \gamma \mathrm{RIII}$ a are activating receptors characterized by the presence of an immunoreceptor tyrosine-based activation motif (ITAM); Fc $\gamma$ RIIIb is unique, as it is anchored by a glycosylphosphatidylinositol (GPI) anchor. In contrast, Fc $\gamma$ RIIb is an inhibitory receptor that contains an immunoreceptor tyrosine-based inhibitory motif (ITIM) in its cytoplasmic domain. The inhibitory receptor Fc $\gamma$ RIIb plays a major role in controlling the antibody and immune response and the development of autoimmune diseases [154-156]. Fc $\gamma$ RIIB includes two isoforms, Fc $\gamma$ RIIB1 and Fc $\gamma$ RIIB2, which transduce inhibitory signals that downregulate immune functions triggered by activating receptors. For instance, Fc $\gamma$ RIIB engagement triggers the blockade of BCR-induced B-cell activation, once it joins with BCR [157]. The opposed signaling pathways of activating and inhibitory $\mathrm{F} c \gamma \mathrm{R}$ act in concert to determine the magnitude of the effector cell responses in immune-complex inflammation and autoimmune disease. In noninflamed tissues, the ratio of activating to inhibitory $\mathrm{F} c \gamma \mathrm{R}$ is low, but it increases markedly in an inflamed environment. Therefore, activating $\mathrm{Fc} \gamma \mathrm{R}$ promotes disease development, while inhibitory $\mathrm{F} c \gamma \mathrm{R}$ contributes to protection in two different ways: first, through the downregulation of effector cell responses and, second, by maintaining peripheral tolerance [158].

Some studies have found promoter mutations that induce lower $F c \gamma R I I B$ expression levels in individuals that are susceptible to autoimmune diseases $[159,160]$. Likewise, it has been reported that $\mathrm{F} c \gamma$ Rs may play a role in the pathogenesis of RA and SLE. Recently, based on specific locus genetic loci studies, $F c \gamma R I I B$ was reported to be associated with
AS development in a case-control study in Han Chinese. That study indicated that rs10917661 may be a novel SNP involved in AS genetic predisposition [161]. In a previous study, we reported the association of rs1801274 (H131R) of Fc $\gamma$ RIIA and rs396991 (V158F) of Fc 2 RIIIA with AS in a small group of patients, having found that the Fc $\gamma$ RIIA$H H$ and $F c \gamma R I I I A-V V$ variants are associated with AS [162]. We therefore suggested that these polymorphisms could be related to the IgG3 immune response against bacterial antigens, as previously reported [163], and to human and bacterial HSP60 [164]. Moreover, a relation between the Fc $\gamma$ RIIIA- $V V$ genotype and the response to infliximab has also been found [165]. These discoveries are important for our understanding of the association between FcR $\gamma$ and the pathogenesis of AS, but more research is required in this field, including replication of the association of $F c \gamma R I I B, F c \gamma R I I A$, and Fc $\gamma$ RIIIA with AS in multiple cohorts and ethnicities, to ascertain whether these SNPs are linked with predisposition to AS.

4.5. Tumor Necrosis Factor-Alpha (TNF- $\alpha)$. Tumor necrosis factor-alpha is a highly potent proinflammatory molecule and a key signaling component of the immune system that is strongly induced after infection or tissue injury [166]. This cytokine is known to be present at higher concentrations in patients with AS, RA, and PsA. The important role of TNF in these diseases has been proven by their successful treatment with anti-TNF drugs [166-168], particularly AS patients respond well to TNF- $\alpha$ antagonist therapy [169].

Indeed, anti-TNF- $\alpha$ therapy has become the standard of care for AS patients over the last decade. Several studies have shown that TNF- $\alpha$ blocking agents, such as infliximab, etanercept, and adalimumab are highly efficacious in controlling inflammation and improving the clinical assessment of AS patients [167, 170-172].

A prospective study showed that three years of TNF- $\alpha$ blocking therapy result in a significant increase in the bone formation marker after three months, a result that continued at a higher level up to three years, leading to a bone turnover balance that favors bone formation, in combination with continuous improvements in bone mineral density (BMD) in the lumbar spine [173]. Furthermore, bisphosphonates in conjunction with anti-TNF agents have a synergistic effect that provides additional increases in the BMD of AS patients [174]. This suggests that TNF- $\alpha$ blockades may even reinforce extensive bone formation by suppressing the inflammatory component of AS.

The TNFA gene contains several SNPs [175], the most widely studied of which is -308 A/G SNP (rs1800629), and $-238 \mathrm{~A} / \mathrm{G}$ (rs361525) in the promoter region. It has been found to be involved in many diseases due to its ability to modify cytokine levels and clinical outcomes [176, 177]. The $-308 \mathrm{~A} / \mathrm{G}$ and $-238 \mathrm{~A} / \mathrm{G}$ transition seems to be associated with susceptibility to autoimmune diseases, although other SNP at -1031 (rs1799964), -863 (rs1800630), -857 ( rs1799724), and -238 (rs361525) in the promoter region of TNFA have been evaluated in AS (Table 4).

However, there are contradictory results, because some studies did not found association between the -238 and 
TABLE 3: Association studies for ERAP1 and ankylosing spondylitis.

\begin{tabular}{|c|c|c|c|c|c|}
\hline Population & Year & Study type & SNP & Association & Reference \\
\hline UK & 2007 & GWAS & $\begin{array}{c}\text { rs30187 } \\
\text { rs27044 } \\
\text { rs17482078 } \\
\text { rs10050860 } \\
\text { rs2287987 }\end{array}$ & $\begin{array}{c}\text { Risk } \\
\text { Risk } \\
\text { NS } \\
\text { NS } \\
\text { NS }\end{array}$ & [109] \\
\hline Australian, British, US ${ }^{1}$ & 2010 & GWAS & $\begin{array}{l}\text { rs27434 } \\
\text { rs27037 }\end{array}$ & $\begin{array}{l}\text { Risk } \\
\text { Risk }\end{array}$ & {$[110]$} \\
\hline UK, Australian, Canadian & 2011 & GWAS & rs30187 & Risk & {$[111]$} \\
\hline Canadian & 2010 & GWAS & $\begin{array}{c}\text { rs30187 } \\
\text { rs27044 } \\
\text { rs10050860 }\end{array}$ & $\begin{array}{c}\text { Risk } \\
\text { No association } \\
\text { No association }\end{array}$ & {$[112]$} \\
\hline Portuguese & 2009 & Case control & $\begin{array}{c}\text { rs27044, } \\
\text { rs17482078 } \\
\text { rs10050860 } \\
\text { rs30187 } \\
\text { rs2287987 }\end{array}$ & $\begin{array}{c}\text { Risk } \\
\text { NS } \\
\text { NS } \\
\text { Risk } \\
\text { NS } \\
\end{array}$ & {$[113]$} \\
\hline $\mathrm{UK}^{1}$ & 2009 & Case control & $\begin{array}{c}\text { rs } 28366066 \\
\text { rs26653 } \\
\text { rs2287987 } \\
\text { rs27434 } \\
\text { rs30187 } \\
\text { rs10050860 } \\
\text { rs } 469783 \\
\text { rs17482078 } \\
\text { rs1065407 } \\
\text { rs13167972 }\end{array}$ & $\begin{array}{l}\text { Protection } \\
\text { Risk } \\
\text { Protection } \\
\text { Risk } \\
\text { Risk } \\
\text { Protection } \\
\text { Risk } \\
\text { Protection } \\
\text { Protection } \\
\text { Protection }\end{array}$ & {$[114]$} \\
\hline Canadian & 2009 & Case control & $\begin{array}{c}\text { rs27044 } \\
\text { rs10050860 } \\
\text { rs30187 } \\
\text { rs26618 } \\
\text { rs26653 } \\
\text { rs3734016 }\end{array}$ & $\begin{array}{c}\text { NS } \\
\text { Protection } \\
\text { Risk } \\
\text { NS } \\
\text { Risk } \\
\text { NS }\end{array}$ & {$[115]$} \\
\hline Han Chinese $^{1}$ & 2009 & Case control & $\begin{array}{l}\text { rs27037 } \\
\text { rs27980 } \\
\text { rs27433 } \\
\text { rs27038 }\end{array}$ & $\begin{array}{c}\text { Risk } \\
\text { Protection } \\
\text { Risk } \\
\text { Risk }\end{array}$ & {$[116]$} \\
\hline Hungarian & 2010 & Case control & $\begin{array}{c}\text { rs } 27044 \\
\text { rs17482078 } \\
\text { rs10050860 } \\
\text { rs30187 } \\
\text { rs2287987 }\end{array}$ & $\begin{array}{c}\text { Risk } \\
\text { NS } \\
\text { Protection } \\
\text { NS } \\
\text { Protection }\end{array}$ & {$[117]$} \\
\hline Korean & 2010 & Case control & $\begin{array}{c}\text { rs27044 } \\
\text { rs30187 } \\
\text { rs17482078 } \\
\text { rs10050860 } \\
\text { rs2287987 }\end{array}$ & $\begin{array}{c}\text { Risk } \\
\text { Risk } \\
\text { No association } \\
\text { No association } \\
\text { No association }\end{array}$ & {$[118]$} \\
\hline Han Chinese & 2011 & Case control & $\begin{array}{l}\text { rs27038 } \\
\text { rs27037 }\end{array}$ & $\begin{array}{l}\text { Risk } \\
\text { Risk } \\
\end{array}$ & [119] \\
\hline Han Chinese & 2011 & Case control & rs27044 & NS & [120] \\
\hline Spanish & 2011 & Case control & $\begin{array}{c}\text { rs17481856 } \\
\text { rs17482078 } \\
\text { rs30187 } \\
\text { rs2287987 } \\
\text { rs27895 } \\
\text { rs27044 } \\
\text { rs26653 } \\
\text { rs10050860 }\end{array}$ & $\begin{array}{c}\text { NS } \\
\text { Risk } \\
\text { Risk } \\
\text { Risk } \\
\text { NS } \\
\text { NS } \\
\text { Risk } \\
\text { Risk }\end{array}$ & {$[121]$} \\
\hline
\end{tabular}


TABLE 3: Continued.

\begin{tabular}{|c|c|c|c|c|c|}
\hline Population & Year & Study type & SNP & Association & Reference \\
\hline Han Chinese & 2011 & Case control & $\begin{array}{l}\text { rs27434, } \\
\text { rs27529 }\end{array}$ & $\begin{array}{l}\text { Risk } \\
\text { Risk }\end{array}$ & {$[122]$} \\
\hline Iranian & 2012 & Case control & $\begin{array}{c}\text { rs30187 } \\
\text { rs27434 } \\
\text { rs469876 } \\
\text { rs13167972 }\end{array}$ & $\begin{array}{c}\text { Risk } \\
\text { Risk } \\
\text { NS } \\
\text { NS }\end{array}$ & [123] \\
\hline European, Asian & 2011 & Meta-analysis & $\begin{array}{l}\text { rs27044 } \\
\text { rs30187 }\end{array}$ & $\begin{array}{l}\text { Risk } \\
\text { Risk }\end{array}$ & [124] \\
\hline European & 2011 & Meta-analysis & $\begin{array}{c}\text { rs17482078, } \\
\text { rs10050860 } \\
\text { rs } 2287987\end{array}$ & $\begin{array}{l}\text { Protection } \\
\text { Protection } \\
\text { Protection }\end{array}$ & \\
\hline All cases & 2012 & Meta-analysis & $\begin{array}{c}\text { rs27044 } \\
\text { rs17482078 } \\
\text { rs10050860 } \\
\text { rs30187 } \\
\text { rs2287987 } \\
\text { rs27037 }\end{array}$ & $\begin{array}{c}\text { Risk } \\
\text { Risk } \\
\text { Protection } \\
\text { Risk } \\
\text { Protection } \\
\text { Risk }\end{array}$ & {$[125]$} \\
\hline
\end{tabular}

GWAS: genome-wide association study.

${ }^{1}$ Only the SNPs associated with AS were included.

NS: not significant.

TABLE 4: Association studies of TNFA polymorphisms with ankylosing spondylitis.

\begin{tabular}{|c|c|c|c|c|c|}
\hline Population & Year & Study type & SNP & Association & Reference \\
\hline Greek & 2009 & Case control & $\begin{array}{c}\text { rs1799724 } \\
\text { rs1800629 } \\
\text { rs361525 }\end{array}$ & $\begin{array}{c}\text { Risk } \\
\text { NS } \\
\text { Not } \mathrm{H}_{-} \mathrm{W}^{*} \\
\text { equilibrium }\end{array}$ & [126] \\
\hline Various & 2011 & Meta-analysis & $\begin{array}{c}\text { rs } 361525 \\
\text { rs1800629 }\end{array}$ & $\begin{array}{l}\text { NS } \\
\text { NS }\end{array}$ & {$[127]$} \\
\hline Various & 2010 & Meta-analysis & $\begin{array}{c}\text { rs1800629 } \\
\text { rs361525 }\end{array}$ & $\begin{array}{l}\text { NS } \\
\text { NS }\end{array}$ & {$[128]$} \\
\hline German & 2011 & Case control & $\begin{array}{c}\text { rs1800629 } \\
\text { rs361525 }\end{array}$ & $\begin{array}{l}\text { NS } \\
\text { NS }\end{array}$ & [129] \\
\hline Colombian & 2012 & Case control & rs1800629 & NS & [130] \\
\hline Mexican & 2006 & Case control & $\begin{array}{c}\mathrm{rs} 1800629 \\
\mathrm{rs} 361525\end{array}$ & $\begin{array}{l}\text { NS } \\
\text { NS }\end{array}$ & {$[131]$} \\
\hline Iranian & 2009 & Case control & $\begin{array}{c}\text { rs1800629 } \\
\text { rs361525 }\end{array}$ & $\begin{array}{c}\text { NS } \\
\text { Risk/Protection (allele } \\
\text { A/G) } \\
\end{array}$ & {$[132]$} \\
\hline Taiwanese & 2007 & Case control & $\begin{array}{c}\mathrm{rs} 1800629 \\
\mathrm{rs} 361525\end{array}$ & $\begin{array}{c}\mathrm{NS} \\
\text { protection }\end{array}$ & {$[133]$} \\
\hline
\end{tabular}

${ }^{*} \mathrm{H}-\mathrm{W}$ : Hardy-Weinberg.

NS: not significant.

-308 polymorphisms of TNFA with AS [126-131], although the A allele and the AA genotype of TNFA (-308 and -238) have been associated with AS, and with a higher production of TNF- $\alpha$ in two populations, which could leads to a state of latent inflammation and subsequent tissue damage, confirming the participation of elevated levels of this cytokine in establishing the inflammatory process in this disease $[132,133]$. In this regard, a Swedish group has reported that patients with AS, AR, and PsA who carry the GG genotype exclusively showed a good response to antiTNF- $\alpha$ therapy, whereas a moderate response was associated with the $-308 \mathrm{~A} / \mathrm{G}$ genotype and unresponsiveness with the AA genotype [178]. These results emphasize the importance of TNFA polymorphism as a predictor of responses to TNF- $\alpha$ blocking agents.

In contrast, a meta-analysis conducted by Lee and Song (2009) failed to demonstrate any association of the TNFA -308 polymorphisms with AS in Europeans [127], leaving several open questions as to the importance of the role of TNFA polymorphisms in AS.

TNF- $\alpha$ is synthesized and expressed on the cell surface as a transmembrane protein (tmTNF- $\alpha$ ) that can be processed 
by the TNF- $\alpha$ converting enzyme to generate a soluble form $($ sTNF- $\alpha)$ [179]. Both the soluble and transmembrane forms of TNF- $\alpha$ are biologically active in their trimeric forms [180, 181] and act by binding two different receptors, TNFR1, which is activated by both sTNF- $\alpha$ and tmTNF- $\alpha$, and TNFR2, which is activated mainly by tmTNF- $\alpha[167,182]$.

TNFR-1 is the primary signaling receptor on most cell types and accounts for the majority of the proinflammatory, cytotoxic, and apoptotic effects classically attributed to TNF$\alpha[183,184]$. In contrast, TNFR2 predominantly mediates signals promoting lymphocyte activation and proliferation [181]. Therefore, at least in the inflammatory environment, the TNF- $\alpha$ /TNFR2 pathway is critical for stabilizing the Tregcell pool that is required to restrain the magnitude and length of an inflammatory immune response and prevent damage to self-tissues $[185,186]$. Moreover, several polymorphisms of the TNFRs may contribute to the development of an abnormal immune response in AS.

In the Mexican population, the work group of CoronaSanchez et al. found a high frequency of the AA genotype of the -383 TNFR1 polymorphism in patients with AS. In addition, the A allele is significantly associated with a higher risk of AS [187].

4.6. Concluding Remarks. Ankylosing spondylitis is a multifactorial disease. HLA-B27 has been associated with AS since 1973; however, different pathways have been described to explain this association. These pathways include the KIRs receptors that could interact with HLA-B27. These receptors are expressed by NK cells, but the involvement of NK cells in AS takes place not only through recognition of HLA-B27, but also through the secretion of proinflammatory cytokines and their effect on Tregs. New participants in the inflammatory process are Th17 cells that induce the secretion of cytokines, such as TNF- $\alpha$, which is clearly involved in the pathogenesis of AS.

The genetic factor has been analyzed in studies of several of the genes involved in the immune response, and particularly in inflammatory responses. The SNPs included suggest that these variations could play a role in AS because of their functional effect on the expression of the genes. Describing the cells and genes associated with this disease is the first step towards the eventual detection of possible therapeutic targets that could be used to improve current treatments and patients' quality of life. However, it is necessary to analyze the functional role of these genes and cells in the pathogenesis of the disease in order to reach an understanding of the mechanisms of these cells and genes in the pathogenesis of AS.

\section{References}

[1] M. Ehrenfeld, "Spondyloarthropathies," Best Practice and Research: Clinical Rheumatology, vol. 26, no. 1, pp. 135-145, 2012.

[2] J. Braun and J. Sieper, “Ankylosing spondylitis," Lancet, vol. 369, no. 9570, pp. 1379-1390, 2007.

[3] A. Ebringer and C. Wilson, "HLA molecules, bacteria and autoimmunity," Journal of Medical Microbiology, vol. 49, no. 4, pp. 305-311, 2000.
[4] E. Feldtkeller, M. A. Khan, D. van der Heijde, S. van der Linden, and J. Braun, "Age at disease onset and diagnosis delay in HLAB27 negative vs. positive patients with ankylosing spondylitis," Rheumatology International, vol. 23, no. 2, pp. 61-66, 2003.

[5] S. van der Linden, H. A. Valkenburg, and A. Cats, "Evaluation of diagnostic criteria for ankylosing spondylitis. A proposal for modification of the New York criteria," Arthritis and Rheumatism, vol. 27, no. 4, pp. 361-368, 1984.

[6] M. A. Brown, "Breakthroughs in genetic studies of ankylosing spondylitis," Rheumatology, vol. 47, no. 2, pp. 132-137, 2008.

[7] D. A. Brewerton, F. D. Hart, A. Nicholls, M. Caffrey, D. C. James, and R. D. Sturrock, "Ankylosing spondylitis and HL-A 27," Lancet, vol. 1, no. 7809, pp. 904-907, 1973.

[8] L. Schlosstein, P. I. Terasaki, R. Bluestone, and C. M. Pearson, "High association of an HL-A antigen, W27, with ankylosing spondylitis," New England Journal of Medicine, vol. 288, no. 14, pp. 704-706, 1973.

[9] J. D. Reveille and F. C. Arnett, "Spondyloarthritis: update on pathogenesis and management," American Journal of Medicine, vol. 118, no. 6, pp. 592-603, 2005.

[10] S. M. van der Linden, H. A. Valkenburg, B. M. de Jongh, and A. Cats, "The risk of developing ankylosing spondylitis in HLA-B27 positive individuals. A comparison of relatives of spondylitis patients with the general population," Arthritis and Rheumatism, vol. 27, no. 3, pp. 241-249, 1984.

[11] M. A. Brown, K. D. Pile, L. G. Kennedy et al., "HLA class I associations of ankylosing spondylitis in the white population in the United Kingdom," Annals of the Rheumatic Diseases, vol. 55, no. 4, pp. 268-270, 1996.

[12] J. D. Reveille, "Major histocompatibility genes and ankylosing spondylitis," Best Practice and Research: Clinical Rheumatology, vol. 20, no. 3, pp. 601-609, 2006.

[13] J. T. Gran, G. Husby, and M. Hordvik, "Prevalence of ankylosing spondylitis in males and females in a young middle-aged population of Tromso, northern Norway," Annals of the Rheumatic Diseases, vol. 44, no. 6, pp. 359-367, 1985.

[14] J. Braun, M. Bollow, G. Remlinger et al., "Prevalence of spondylarthropathies in HLA-B27 positive and negative blood donors," Arthritis and Rheumatism, vol. 41, no. 1, pp. 58-67, 1998.

[15] J. D. Reveille, E. J. Ball, and M. A. Khan, "HLA-B27 and genetic predisposing factors in spondyloarthropathies," Current Opinion in Rheumatology, vol. 13, no. 4, pp. 265-272, 2001.

[16] M. A. Brown, B. P. Wordsworth, and J. D. Reveille, "Genetics of ankylosing spondylitis," Clinical and Experimental Rheumatology, vol. 20, no. 6, supplement 28, pp. S43-S49, 2002.

[17] J. B. Armas, S. Gonzalez, J. Martinez-Borra et al., "Susceptibility to ankylosing spondylitis is independent of the Bw4 and Bw6 epitopes of HLA-B27 alleles," Tissue Antigens, vol. 53, no. 3, pp. 237-243, 1999.

[18] I. L. MacLean, S. Iqball, P. Woo et al., "HLA-B27 subtypes in the spondarthropathies," Clinical and Experimental Immunology, vol. 91, no. 2, pp. 214-219, 1993.

[19] C. López-Larrea, S. Gonzalez-Roces, and V. Alvarez, "HLA-B27 structure, function, and disease association," Current Opinion in Rheumatology, vol. 8, no. 4, pp. 296-308, 1996.

[20] E. J. Ball and M. A. Khan, "HLA-B27 polymorphism," Joint Bone Spine, vol. 68, no. 5, pp. 378-382, 2001.

[21] M. D’Amato, M. T. Fiorillo, C. Carcassi et al., "Relevance of residue 116 of HLA-B27 in determining susceptibility to ankylosing spondylitis," European Journal of Immunology, vol. 25, no. 11, pp. 3199-3201, 1995. 
[22] F. Paladini, E. Taccari, M. T. Fiorillo et al., "Distribution of HLAB27 subtypes in Sardinia and continental Italy and their association with spondylarthropathies," Arthritis and Rheumatism, vol. 52, no. 10, pp. 3319-3321, 2005.

[23] E. Nurzia, D. Narzi, A. Cauli et al., "Interaction pattern of Arg 62 in the a-pocket of differentially disease-associated HLA-B27 subtypes suggests distinct TCR binding modes," PLOS ONE, vol. 7, no. 3, Article ID e32865, 2012.

[24] J. A. Smith, E. Märker-Hermann, and R. A. Colbert, "Pathogenesis of ankylosing spondylitis: current concepts," Best Practice and Research: Clinical Rheumatology, vol. 20, no. 3, pp. 571-591, 2006.

[25] A. Ziegler, B. Loll, R. Misselwitz, and B. Uchanska-Ziegler, "Implications of structural and thermodynamic studies of HLAB27 subtypes exhibiting differential association with ankylosing spondylitis," Advances in Experimental Medicine and Biology, vol. 649, pp. 177-194, 2009.

[26] L. A. Bird, C. A. Peh, S. Kollnbeger, T. Elliott, A. J. McMichael A.J., and P. Bowness, "Lymphoblastoid cells express HLA-B27 homodimers both intracellularly and at the cell surface following endosomal recycling," European Journal of Immunology, vol. 33, no. 3, pp. 748-759, 2003.

[27] S. Kollnberger, L. Bird, M. Y. Sun et al., "Cell-surface expression and immune receptor recognition of HLA-B27 homodimers," Arthritis and Rheumatism, vol. 46, no. 11, pp. 2972-2982, 2002.

[28] R. L. Allen and J. Trowsdale, "Recognition of classical and heavy chain forms of HLA-B27 by leukocyte receptors," Current Molecular Medicine, vol. 4, no. 1, pp. 59-65, 2004.

[29] A. T. Chan, S. D. Kollnberger, L. R. Wedderburn, and P. Bowness, "Expansion and enhanced survival of natural killer cells expressing the killer immunoglobulin-like receptor KIR3DL2 in spondylarthritis," Arthritis and Rheumatism, vol. 52, no. 11, pp. 3586-3595, 2005.

[30] M. Marcilla and J. A. López de Castro, "Peptides: the cornerstone of HLA-B27 biology and pathogenetic role in spondyloarthritis," Tissue Antigens, vol. 71, no. 6, pp. 495-506, 2008.

[31] M. N. Vázquez and J. A. López de Castro, "Similar cell surface expression of $\beta 2$-microglobulin-free heavy chains by HLA-B27 subtypes differentially associated with ankylosing spondylitis," Arthritis and Rheumatism, vol. 52, no. 10, pp. 3290-3299, 2005.

[32] G. P. Thomas and M. A. Brown, "Genetics and genomics of ankylosing spondylitis," Immunological Reviews, vol. 233, no. 1, pp. 162-180, 2010.

[33] J. P. Mear, K. L. Schreiber, C. Münz et al., "Misfolding of HLAB27 as a result of its B pocket suggests a novel mechanism for its role in susceptibility to spondyloarthropathies," Journal of Immunology, vol. 163, no. 12, pp. 6665-6670, 1999.

[34] M. L. DeLay, M. J. Turner, E. I. Klenk, J. A. Smith, D. P. Sowders, and R. A. Colbert, "HLA-B27 misfolding and the unfolded protein response augment interleukin-23 production and are associated with Th17 activation in transgenic rats," Arthritis and Rheumatism, vol. 60, no. 9, pp. 2633-2643, 2009.

[35] R. A. Colbert, M. L. DeLay, G. Layh-Schmitt, and D. P. Sowders, "HLA-B27 misfolding and spondyloarthropathies", Prion, vol. 3, no. 1, pp. 15-26, 2009.

[36] H. L. Pahl and P. A. Baeuerle, "The ER overload response: activation of NF- $\kappa \mathrm{B}$," Trends in Biochemical Sciences, vol. 22, no. 2, pp. 63-67, 1997.

[37] M. Virtala, J. Kirveskari, and K. Granfors, "HLA-B27 modulates the survival of Salmonella enteritidis in transfected L cells, possibly by impaired nitric oxide production," Infection and Immunity, vol. 65, no. 10, pp. 4236-4242, 1997.
[38] Y. Jiang, R. Zhang, J. Zheng et al., "Meta-analysis of 125 rheumatoid arthritis-related single nucleotide polymorphisms studied in the past two decades," PloS One, vol. 7, no. 12, Article ID e51571, 2012.

[39] A. Mathieu, F. Paladini, A. Vacca, A. Cauli, M. T. Fiorillo, and R. Sorrentino, "The interplay between the geographic distribution of HLA-B27 alleles and their role in infectious and autoimmune diseases: a unifying hypothesis," Autoimmunity Reviews, vol. 8, no. 5, pp. 420-425, 2009.

[40] P. Miossec and J. K. Kolls, "Targeting IL-17 and TH17 cells in chronic inflammation," Nature Reviews Drug Discovery, vol. 11, no. 10, pp. 763-776, 2012.

[41] N. Yeremenko and D. Baeten, "IL-17 in spondyloarthritis: is the T-party over?" Arthritis Research and Therapy, vol. 13, no. 3, article 115, 2011.

[42] A. Taylan, I. Sari, D. L. Kozaci et al., "Evaluation of the T helper 17 axis in ankylosing spondylitis," Rheumatology International, vol. 32, no. 8, pp. 2511-2515, 2012.

[43] H. Shen, J. C. Goodall, and J. S. Hill Gaston, "Frequency and phenotype of peripheral blood Th17 cells in ankylosing spondylitis and rheumatoid arthritis," Arthritis and Rheumatism, vol. 60, no. 6, pp. 1647-1656, 2009.

[44] A. Di Cesare, P. Di Meglio, and F. O. Nestle, "The IL-23Th17 axis in the immunopathogenesis of psoriasis," Journal of Investigative Dermatology, vol. 129, no. 6, pp. 1339-1350, 2009.

[45] P. P. Ahern, A. Izcue, K. J. Maloy, and F. Powrie, "The interleukin-23 axis in intestinal inflammation," Immunological Reviews, vol. 226, no. 1, pp. 147-159, 2008.

[46] L. Limón-Camacho, M. I. Vargas-Rojas, J. Vázquez-Mellado et al., "In vivo peripheral blood proinflammatory $\mathrm{T}$ cells in patients with ankylosing spondylitis," Journal of Rheumatology, vol. 39, no. 4, pp. 830-835, 2012.

[47] L. E. Harrington, R. D. Hatton, P. R. Mangan et al., "Interleukin 17-producing CD4+ effector T cells develop via a lineage distinct from the T helper type 1 and 2 lineages," Nature Immunology, vol. 6, no. 11, pp. 1123-1132, 2005.

[48] Y. Iwakura and H. Ishigame, "The IL-23/IL-17 axis in inflammation," Journal of Clinical Investigation, vol. 116, no. 5, pp. 12181222, 2006.

[49] T. Noordenbos, N. Yeremenko, I. Gofita et al., "Interleukin17-positive mast cells contribute to synovial inflammation in spondylarthritis," Arthritis and Rheumatism, vol. 64, no. 1, pp. 99-109, 2012.

[50] L. Zhang, Y. G. Li, Y. H. Li et al., "Increased frequencies of th22 cells as well as th17 cells in the peripheral blood of patients with ankylosing spondylitis and rheumatoid arthritis," PLOS ONE, vol. 7, no. 4, Article ID e31000, 2012.

[51] L. Xueyi, C. Lina, W. Zhenbiao, H. Qing, L. Qiang, and P. Zhu, "Levels of circulating Thl7 cells and regulatory T cells in ankylosing spondylitis patients with an inadequate response to anti-TNF-alpha therapy," Journal of Clinical Immunology, vol. 33, no. 1, pp. 151-161, 2013.

[52] C. Jandus, G. Bioley, J. P. Rivals, J. Dudler, D. Speiser, and P. Romero, "Increased numbers of circulating polyfunctional Th17 memory cells in patients with seronegative spondylarthritides," Arthritis and Rheumatism, vol. 58, no. 8, pp. 2307-2317, 2008.

[53] Y. Mei, F. Pan, J. Gao et al., "Increased serum IL-17 and IL-23 in the patient with ankylosing spondylitis," Clinical Rheumatology, vol. 30, no. 2, pp. 269-273, 2011.

[54] T. J. Kenna, S. I. Davidson, R. Duan et al., "Enrichment of circulating interleukin-17-secreting interleukin-23 receptor-positive 
$\gamma / \delta \mathrm{T}$ cells in patients with active ankylosing spondylitis," Arthritis and Rheumatism, vol. 64, no. 5, pp. 1420-1429, 2012.

[55] W. P. Maksymowych, P. Chiowchanwisawakit, T. Clare, S. J. Pedersen, M. Østergaard, and R. G. W. Lambert, "Inflammatory lesions of the spine on magnetic resonance imaging predict the development of new syndesmophytes in ankylosing spondylitis evidence of a relationship between inflammation and new bone formation," Arthritis and Rheumatism, vol. 60, no. 1, pp. 93-102, 2009.

[56] W. P. Maksymowych, D. Elewaut, and G. Schett, "Motion for debate: the development of ankylosis in ankylosing spondylitis is largely dependent on inflammation," Arthritis and Rheumatism, vol. 64, no. 6, pp. 1713-1719, 2012.

[57] G. Schett, "Independent development of inflammation and new bone formation in ankylosing spondylitis," Arthritis and Rheumatism, 2012.

[58] D. van der Heijde, R. Landewé, S. Einstein et al., "Radiographic progression of ankylosing spondylitis after up to two years of treatment with etanercept," Arthritis and Rheumatism, vol. 58, no. 5, pp. 1324-1331, 2008.

[59] L. M. Francisco, P. T. Sage, and A. H. Sharpe, "The PD-1 pathway in tolerance and autoimmunity," Immunological Reviews, vol. 236, no. 1, pp. 219-242, 2010.

[60] D. J. Campbell and M. A. Koch, "Phenotypical and functional specialization of FOXP3+ regulatory T cells," Nature Reviews Immunology, vol. 11, no. 2, pp. 119-130, 2011.

[61] E. Azizi, A. Massoud, A. A. Amirzargar et al., "Association of CTLA4 gene polymorphism in iranian patients with ankylosing spondylitis," Journal of Clinical Immunology, vol. 30, no. 2, pp. 268-271, 2010.

[62] Y. H. Lee, J. D. Ji, J. Sohn, and G. G. Song, "Polymorphisms of CTLA- 4 exon $1+49$, CTLA- 4 promoter -318 and Fas promoter -670 in spondyloarthropathies," Clinical Rheumatology, vol. 20, no. 6, pp. 420-422, 2001.

[63] W. Y. Lee, Y. H. Chang, M. K. Lo et al., "Polymorphisms of cytotoxic T lymphocyte-associated antigen- 4 and cytokine genes in Taiwanese patients with ankylosing spondylitis," Tissue Antigens, vol. 75, no. 2, pp. 119-126, 2010.

[64] X. Liu, L. H. Hu, Y. R. Li, F. H. Chen, Y. Ning, and Q. F. Yao, "Programmed cell death 1 gene polymorphisms is associated with ankylosing spondylitis in Chinese Han population," Rheumatology International, vol. 31, no. 2, pp. 209-213, 2011.

[65] N. Soleimanifar, A. A. Amirzargar, M. Mahmoudi et al., "Study of programmed cell death 1 (PDCD1) gene polymorphims in Iranian patients with ankylosing spondylitis," Inflammation, vol. 34, no. 6, pp. 707-712, 2011.

[66] C. H. Huang, R. H. Wong, J. C. C. Wei et al., "Effects of genetic polymorphisms of programmed cell death 1 and its ligands on the development of ankylosing spondylitis," Rheumatology, vol. 50, no. 10, pp. 1809-1813, 2011.

[67] S. H. Lee, Y. A. Lee, D. H. Woo et al., "Association of the programmed cell death 1 (PDCD1) gene polymorphism with ankylosing spondylitis in the Korean population," Arthritis Research and Therapy, vol. 8, no. 6, article R163, 2006.

[68] Q. Yang, Y. Liu, D. Liu, Y. Zhang, and K. Mu, "Association of polymorphisms in the programmed cell death 1 (PD-1) and PD-1 ligand genes with ankylosing spondylitis in a Chinese population," Clinical and Experimental Rheumatology, vol. 29, no. 1, pp. 13-18, 2011.

[69] Y. Wu, M. Ren, R. Yang et al., "Reduced immunomodulation potential of bone marrow-derived mesenchymal stem cells induced CCR4+CCR6+ Th/Treg cell subset imbalance in ankylosing spondylitis," Arthritis Research and Therapy, vol. 13, no. 1, article R29, 2011.

[70] S. S. Zhao, J. W. Hu, J. Wang, X. J. Lou, and L. L. Zhou, "Inverse correlation between CD4+CD25highCD127low/- regulatory Tcells and serum immunoglobulin A in patients with newonset ankylosing spondylitis," Journal of International Medical Research, vol. 39, no. 5, pp. 1968-1974, 2011.

[71] H. Appel, P. Wu, R. Scheer et al., "Synovial and peripheral blood CD4+FoxP3+ T cells in spondyloarthritis," Journal of Rheumatology, vol. 38, no. 11, pp. 2445-2451, 2011.

[72] Z. Tian, M. E. Gershwin, and C. Zhang, "Regulatory NK cells in autoimmune disease," Journal of Autoimmunity, vol. 39, no. 3, pp. 206-215, 2012.

[73] N. Azuz-Lieberman, G. Markel, S. Mizrahi et al., "The involvement of NK cells in ankylosing spondylitis," International Immunology, vol. 17, no. 7, pp. 837-845, 2005.

[74] A. R. French and W. M. Yokoyama, "Natural killer cells and autoimmunity," Arthritis Research and Therapy, vol. 6, no. 1, pp. 8-14, 2004.

[75] Y. W. Park, S. J. Kee, Y. N. Cho et al., "Impaired differentiation and cytotoxicity of natural killer cells in systemic lupus erythematosus," Arthritis and Rheumatism, vol. 60, no. 6, pp. 17531763, 2009.

[76] T. Aramaki, H. Ida, Y. Izumi et al., "A significantly impaired natural killer cell activity due to a low activity on a per-cell basis in rheumatoid arthritis," Modern Rheumatology, vol. 19, no. 3, pp. 245-252, 2009.

[77] A. L. Cameron, B. Kirby, and C. E. M. Griffiths, "Circulating natural killer cells in psoriasis," British Journal of Dermatology, vol. 149, no. 1, pp. 160-164, 2003.

[78] D. Schepis, I. Gunnarsson, M. L. Eloranta et al., "Increased proportion of CD56bright natural killer cells in active and inactive systemic lupus erythematosus," Immunology, vol. 126, no. 1, pp. 140-146, 2009.

[79] S. Szántó, M. Aleksza, E. Mihály et al., "Intracytoplasmic cytokine expression and $\mathrm{T}$ cell subset distribution in the peripheral blood of patients with ankylosing spondylitis," Journal of Rheumatology, vol. 35, no. 12, pp. 2372-2375, 2008.

[80] T. Mousavi, H. Poormoghim, M. Moradi, N. Tajik, F. Shahsavar, and M. Soofi, "Phenotypic study of natural killer cell subsets in ankylosing spondylitis patients," Iranian Journal of Allergy, Asthma and Immunology, vol. 8, no. 4, pp. 193-198, 2009.

[81] F. Ciccia, A. Accardo-Palumbo, R. Alessandro et al., "Interleukin-22 and interleukin-22-producing NKp44+ natural killer cells in subclinical gut inflammation in ankylosing spondylitis," Arthritis and Rheumatism, vol. 64, no. 6, pp. 1869-1878, 2012.

[82] I. V. Zvyagin, I. Z. Mamedov, O. V. Britanova et al., "Contribution of functional KIR3DL1 to ankylosing spondylitis," Cellular and Molecular Immunology, vol. 7, no. 6, pp. 471-476, 2010.

[83] I. Wong-Baeza, A. Ridley, J. Shaw et al., "KIR3DL2 binds to HLA-B27 dimers and free $\mathrm{H}$ chains more strongly than other HLA class I and promotes the expansion of T cells in ankylosing spondylitis," Journal of Immunology, vol. 190, no. 7, pp. 32163224, 2013.

[84] S. Wang, G. Li, R. Ge et al., "Association of KIR genotype with susceptibility to HLA-B27-positive ankylosing spondylitis," Modern Rheumatology, vol. 23, no. 3, pp. 538-541, 2013.

[85] Y. L. Jiao, B. C. Zhang, L. You et al., "Polymorphisms of KIR gene and HLA-C alleles: possible association with susceptibility to HLA-B27-positive patients with ankylosing spondylitis," Journal of Clinical Immunology, vol. 30, no. 6, pp. 840-844, 2010. 
[86] R. Díaz-Peña, J. R. Vidal-Castiñeira, R. Alonso-Arias et al., "Association of the KIR3DS1*013 and KIR3DL1*004 alleles with susceptibility to ankylosing Spondylitis," Arthritis and Rheumatism, vol. 62, no. 4, pp. 1000-1006, 2010.

[87] R. Díaz-Peña, M. A. Blanco-Gelaz, B. Suárez-Álvarez et al., "Activating KIR genes are associated with ankylosing spondylitis in Asian populations," Human Immunology, vol. 69, no. 7, pp. 437-442, 2008.

[88] N. Tajik, F. Shahsavar, H. Poormoghim, M. F. Radjabzadeh, T. Mousavi, and A. Jalali, "KIR3DL1+HLA-B Bw4 Ile80 and KIR2DS1+HLA-C2 combinations are both associated with ankylosing spondylitis in the Iranian population," International Journal of Immunogenetics, vol. 38, no. 5, pp. 403-409, 2011.

[89] T. Mousavi, H. Poormoghim, M. Moradi, N. Tajik, F. Shahsavar, and B. Asadifar, "Inhibitory killer cell immunoglobulin-like receptor KIR3DL1 in combination with HLA-B Bw4iso protect against Ankylosing spondylitis," Iranian Journal of Immunology, vol. 7, no. 2, pp. 88-95, 2010.

[90] D. Harvey, J. J. Pointon, C. Sleator et al., "Analysis of killer immunoglobulin-like receptor genes in ankylosing spondylitis," Annals of the Rheumatic Diseases, vol. 68, no. 4, pp. 595-598, 2009.

[91] A. G. Pratt, J. D. Isaacs, and D. L. Mattey, "Current concepts in the pathogenesis of early rheumatoid arthritis," Best Practice and Research: Clinical Rheumatology, vol. 23, no. 1, pp. 37-48, 2009.

[92] P. Conigliaro, R. Scrivo, G. Valesini, and R. Perricone, "Emerging role for NK cells in the pathogenesis of inflammatory arthropathies," Autoimmunity Reviews, vol. 10, no. 10, pp. 577$581,2011$.

[93] L. Rivino, P. Gruarin, B. Häringer et al., "CCR6 is expressed on an IL-10-producing, autoreactive memory T cell population with context-dependent regulatory function," Journal of Experimental Medicine, vol. 207, no. 3, pp. 565-577, 2010.

[94] I. Comerford, M. Bunting, K. Fenix et al., "An immune paradox: how can the same chemokine axis regulate both immune tolerance and activation?: CCR6/CCL20: a chemokine axis balancing immunological tolerance and inflammation in autoimmune disease," BioEssays, vol. 32, no. 12, pp. 1067-1076, 2010.

[95] R. Varona, V. Cadenas, L. Gómez, C. Martínez-A, and G. Márquez, "CCR6 regulates CD4+ T-cell-mediated acute graftversus-host disease responses," Blood, vol. 106, no. 1, pp. 18-26, 2005.

[96] Y. Kochi, Y. Okada, A. Suzuki et al., "A regulatory variant in CCR6 is associated with rheumatoid arthritis susceptibility," Nature Genetics, vol. 42, no. 6, pp. 515-519, 2010.

[97] J. H. Ruth, S. Shahrara, C. C. Park et al., "Role of macrophage inflammatory protein-3 $\alpha$ and its ligand CCR6 in rheumatoid arthritis," Laboratory Investigation, vol. 83, no. 4, pp. 579-588, 2003.

[98] C. J. Cohen, T. Karaderi, J. J. Pointon, and B. P. Wordsworth, "A CCR6 variant strongly associated with rheumatoid arthritis in two populations is not associated with ankylosing spondylitis," Rheumatology International, 2012.

[99] W. C. Chang, P. Y. Woon, J. C. Wei et al., "A single-nucleotide polymorphism of CCR6 (rs3093024) is associated with susceptibility to rheumatoid arthritis but not ankylosing spondylitis, in a Taiwanese population," Journal of Rheumatology, vol. 39, no. 8, pp. 1765-1766, 2012.
[100] E. V. Acosta-Rodriguez, L. Rivino, J. Geginat et al., "Surface phenotype and antigenic specificity of human interleukin 17producing T helper memory cells," Nature Immunology, vol. 8, no. 6, pp. 639-646, 2007.

[101] F. Annunziato, L. Cosmi, V. Santarlasci et al., "Phenotypic and functional features of human Th17 cells," Journal of Experimental Medicine, vol. 204, no. 8, pp. 1849-1861, 2007.

[102] A. Moretta and C. Bottino, "Commentary: regulated equilibrium between opposite signals: a general paradigm for $\mathrm{T}$ cell function?" European Journal of Immunology, vol. 34, no. 8, pp. 2084-2088, 2004.

[103] M. Fernández-Mestre, K. Sánchez, O. Balbás et al., "Influence of CTLA-4 gene polymorphism in autoimmune and infectious diseases," Human Immunology, vol. 70, no. 7, pp. 532-535, 2009.

[104] M. F. Gonzalez-Escribano, R. Rodriguez, A. Valenzuela, A. Garcia, J. R. Garcia-Lozano, and A. Nunez-Roldan, "CTLA4 polymorphisms in Spanish patients with rheumatoid arthritis," Tissue Antigens, vol. 53, no. 3, pp. 296-300, 1999.

[105] M. R. Rodríguez, A. Núñez-Roldán, F. Aguilar, A. Valenzuela, A. García, and M. F. González-Escribano, "Association of the CTLA4 $3^{\prime}$ untranslated region polymorphism with the susceptibility to rheumatoid arthritis," Human Immunology, vol. 63, no. 1, pp. 76-81, 2002.

[106] M. Mäurer, S. Loserth, A. Kolb-Mäurer et al., "A polymorphism in the human cytotoxic T-lymphocyte antigen 4 (CTLA4) gene (exon $1+49$ ) alters T-cell activation," Immunogenetics, vol. 54, no. 1, pp. 1-8, 2002.

[107] É. Toussirot, P. Saas, M. Deschamps et al., "Increased production of soluble CTLA-4 in patients with spondylarthropathies correlates with disease activity," Arthritis Research and Therapy, vol. 11, no. 4, article R101, 2009.

[108] G. Zhang, Z. Liu, S. Duan et al., "Association of polymorphisms of programmed cell death-1 gene with chronic hepatitis B virus infection," Human Immunology, vol. 71, no. 12, pp. 1209-1213, 2010.

[109] P. R. Burton, D. G. Clayton, L. R. Cardon et al., "Association scan of 14,500 nonsynonymous SNPs in four diseases identifies autoimmunity variants," Nature Genetics, vol. 39, no. 11, pp. 1329-1337, 2007.

[110] J. D. Reveille, A. M. Sims, P. Danoy et al., "Genome-wide association study of ankylosing spondylitis identifies non-MHC susceptibility loci," Nature Genetics, vol. 42, no. 2, pp. 123-127, 2010.

[111] D. M. Evans, C. C. Spencer, J. J. Pointon et al., "Interaction between ERAP1 and HLA-B27 in ankylosing spondylitis implicates peptide handling in the mechanism for HLA-B27 in disease susceptibility," Nature Genetics, vol. 43, no. 8, pp. 761$767,2011$.

[112] F. W. L. Tsui, N. Haroon, J. D. Reveille et al., "Association of an ERAP1 ERAP2 haplotype with familial ankylosing spondylitis," Annals of the Rheumatic Diseases, vol. 69, no. 4, pp. 733-736, 2010.

[113] F. M. Pimentel-Santos, D. Ligeiro, M. Matos et al., "Association of IL23R and ERAP1 genes with ankylosing spondylitis in a Portuguese population," Clinical and Experimental Rheumatology, vol. 27, no. 5, pp. 800-806, 2009.

[114] D. Harvey, J. J. Pointon, D. M. Evans et al., "Investigating the genetic association between ERAP1 and ankylosing spondylitis," Human Molecular Genetics, vol. 18, no. 21, pp. 4204-4212, 2009.

[115] W. P. Maksymowych, R. D. Inman, D. D. Gladman, J. P. Reeve, A. Pope, and P. Rahman, "Association of a specific ERAP1/ARTS1 
haplotype with disease susceptibility in ankylosing spondylitis," Arthritis and Rheumatism, vol. 60, no. 5, pp. 1317-1323, 2009.

[116] S. I. Davidson, X. Wu, Y. Liu et al., "Association of ERAP1, but not IL23R, with ankylosing spondylitis in a Han Chinese population," Arthritis and Rheumatism, vol. 60, no. 11, pp. 32633268, 2009.

[117] B. Pazár, E. Sáfrány, P. Gergely, S. Szántó, Z. Szekanecz, and G. Poór, "Association of ARTS1 gene polymorphisms with ankylosing spondylitis in the Hungarian population: the rs27044 variant is associated with HLA-B $* 2705$ subtype in Hungarian patients with ankylosing spondylitis," Journal of Rheumatology, vol. 37, no. 2, pp. 379-384, 2010.

[118] C. B. Choi, T. H. Kim, J. B. Jun et al., "ARTS1 polymorphisms are associated with ankylosing spondylitis in Koreans," Annals of the Rheumatic Diseases, vol. 69, no. 3, pp. 582-584, 2010.

[119] S. I. Davidson, Y. Liu, P. A. Danoy et al., "Association of STAT3 and TNFRSF1A with ankylosing spondylitis in Han Chinese," Annals of the Rheumatic Diseases, vol. 70, no. 2, pp. 289-292, 2011.

[120] W. Wu, Y. Ding, Y. Chen et al., "Susceptibility to ankylosing spondylitis: evidence for the role of ERAP1, TGFb1 and TLR9 gene polymorphisms," Rheumatology International, vol. 32, no. 8, pp. 2517-2521, 2012.

[121] M. Szczypiorska, A. Sánchez, N. Bartolomé et al., "ERAP1 polymorphisms and haplotypes are associated with ankylosing spondylitis susceptibility and functional severity in a Spanish population," Rheumatology, vol. 50, no. 11, pp. 1969-1975, 2011.

[122] C. Li, Z. Lin, Y. Xie et al., "ERAP1 is associated with ankylosing spondylitis in Han Chinese," Journal of Rheumatology, vol. 38, no. 2, pp. 317-321, 2011.

[123] M. Mahmoudi, A. R. Jamshidi, A. A. Amirzargar et al., "Association between endoplasmic reticulum aminopeptidase-1 (ERAP1) and susceptibility to ankylosing spondylitis in Iran," Iranian Journal of Allergy, Asthma, and Immunology, vol. 11, no. 4, pp. 294-300, 2012.

[124] Y. H. Lee, S. J. Choi, J. D. Ji, and G. G. Song, "Associations between ERAP1 polymorphisms and ankylosing spondylitis susceptibility: a meta-analysis," Inflammation Research, vol. 60, no. 11, pp. 999-1003, 2011.

[125] R. Chen, L. Yao, T. Meng, and W. Xu, “The association between seven ERAP1 polymorphisms and ankylosing spondylitis susceptibility: a meta-analysis involving 8,530 cases and 12,449 controls," Rheumatology International, vol. 32, no. 4, pp. 909914, 2011.

[126] A. Chatzikyriakidou, I. Georgiou, P. V. Voulgari, and A. A. Drosos, "The role of tumor necrosis factor (TNF)- $\alpha$ and TNF receptor polymorphisms in susceptibility to ankylosing spondylitis," Clinical and Experimental Rheumatology, vol. 27, no. 4, pp. 645-648, 2009.

[127] Y. H. Lee and G. G. Song, "Lack of association of TNF-alpha promoter polymorphisms with ankylosing spondylitis: a metaanalysis," Rheumatology, vol. 48, no. 11, pp. 1359-1362, 2009.

[128] B. Li, P. Wang, and H. Li, "The association between TNF- $\alpha$ promoter polymorphisms and ankylosing spondylitis: a metaanalysis," Clinical Rheumatology, vol. 29, no. 9, pp. 983-990, 2010.

[129] D. A. Poddubnyy, E. Märker-Hermann, W. Kaluza-Schilling et al., "Relation of HLA-B27, tumor necrosis factor- $\alpha$ promoter gene polymorphisms, and $\mathrm{T}$ cell cytokine production in ankylosing spondylitis-a comprehensive genotype-phenotype analysis from an observational cohort," Journal of Rheumatology, vol. 38, no. 11, pp. 2436-2441, 2011.
[130] C. Romero-Sánchez, J. Londoño, G. Delgado et al., "Associationof tumor necrosis factor alpha-308 promoter polymorphism with spondyloarthritides patients in Colombia," Rheumatology International, vol. 32, no. 7, pp. 2195-2197, 2012.

[131] G. Vargas-Alarcón, J. Casasola-Vargas, J. M. Rodríguez-Pérez et al., "Tumor necrosis factor- $\alpha$ promoter polymorphisms in mexican patients with spondyloarthritis," Human Immunology, vol. 67, no. 10, pp. 826-832, 2006.

[132] M. H. Nicknam, M. Mahmoudi, A. A. Amirzargar, A. R. Jamshidi, N. Rezaei, and B. Nikbin, "HLA-B27 subtypes and tumor necrosis factor $\alpha$ promoter region polymorphism in Iranian patients with ankylosing spondylitis," European Cytokine Network, vol. 20, no. 1, pp. 17-20, 2009.

[133] M. Y. Shiau, M. K. Lo, C. P. Chang, T. P. Yang, K. T. Ho, and Y. H. Chang, "Association of tumour necrosis factor $\alpha$ promoter polymorphisms with ankylosing spondylitis in Taiwan," Annals of the Rheumatic Diseases, vol. 66, no. 4, pp. 562-563, 2007.

[134] J. Zúñiga, D. Torres-García, L. Jimenez et al., "PDCD1 gene polymorphisms in different Mexican ethnic groups and their role in the susceptibility to hypersensitivity pneumonitis," Clinical Biochemistry, vol. 43, no. 10-11, pp. 929-931, 2010.

[135] G. Kochan, T. Krojer, D. Harvey et al., "Crystal structures of the endoplasmic reticulum aminopeptidase-1 (ERAP1) reveal the molecular basis for N-terminal peptide trimming," Proceedings of the National Academy of Sciences of the United States of America, vol. 108, no. 19, pp. 7745-7750, 2011.

[136] S. Kim, S. Lee, J. Shin et al., "Human cytomegalovirus microRNA miR-US4-1 inhibits CD8+ $\mathrm{T}$ cell responses by targeting the aminopeptidase ERAP1," Nature Immunology, vol. 12, no. 10, pp. 984-991, 2011.

[137] Y. Goto, H. Tanji, A. Hattori, and M. Tsujimoto, "Glutamine-181 is crucial in the enzymatic activity and substrate specificity of human endoplasmic-reticulum aminopeptidase-1," Biochemical Journal, vol. 416, no. 1, pp. 109-115, 2008.

[138] L. Saveanu, O. Carroll, V. Lindo et al., "Concerted peptide trimming by human ERAP1 and ERAP2 aminopeptidase complexes in the endoplasmic reticulum," Nature Immunology, vol. 6, no. 7, pp. 689-697, 2005.

[139] A. F. Kisselev, T. N. Akopian, K. M. Woo, and A. L. Goldberg, "The sizes of peptides generated from protein by mammalian 26 and $20 \mathrm{~S}$ proteasomes. Implications for understanding the degradative mechanism and antigen presentation," Journal of Biological Chemistry, vol. 274, no. 6, pp. 3363-3371, 1999.

[140] M. J. Androlewicz, K. S. Anderson, and P. Cresswell, "Evidence that transporters associated with antigen processing translocate a major histocompatibility complex class I-binding peptide into the endoplasmic reticulum in an ATP-dependent manner," Proceedings of the National Academy of Sciences of the United States of America, vol. 90, no. 19, pp. 9130-9134, 1993.

[141] J. J. Neefjes, F. Momburg, and G. J. Hammerling, "Selective and ATP-dependent translocation of peptides by the MHC-encoded transporter," Science, vol. 261, no. 5122, pp. 769-771, 1993.

[142] P. M. van Endert, R. Tampé, T. H. Meyer, R. Tisch, J. F. Bach, and H. O. McDevitt, "A sequential model for peptide binding and transport by the transporters associated with antigen processing," Immunity, vol. 1, no. 6, pp. 491-500, 1994.

[143] I. A. York, S. C. Chang, T. Saric et al., "The ER aminopeptidase ERAP I enhances or limits antigen presentation by trimming epitopes to 8-9 residues," Nature Immunology, vol. 3, no. 12, pp. 1177-1184, 2002.

[144] S. C. Chang, F. Momburg, N. Bhutani, and A. L. Goldberg, "The ER aminopeptidase, ERAP1, trims precursors to lengths 
of MHC class I peptides by a "molecular ruler" mechanism," Proceedings of the National Academy of Sciences of the United States of America, vol. 102, no. 47, pp. 17107-17112, 2005.

[145] X. Cui, F. Hawari, S. Alsaaty et al., "Identification of ARTS1 as a novel TNFR1-binding protein that promotes TNFR1 ectodomain shedding," Journal of Clinical Investigation, vol. 110, no. 4, pp. 515-526, 2002.

[146] X. Cui, F. N. Rouhani, F. Hawari, and S. J. Levine, "Shedding of the type II IL-1 decoy receptor requires a multifunctional aminopeptidase, aminopeptidase regulator of TNF receptor type 1 shedding," Journal of Immunology, vol. 171, no. 12, pp. 6814-6819, 2003.

[147] X. Cui, F. N. Rouhani, F. Hawari, and S. J. Levine, "An aminopeptidase, ARTS-1, is required for interleukin-6 receptor shedding," Journal of Biological Chemistry, vol. 278, no. 31, pp. 28677-28685, 2003.

[148] N. Haroon, F. W. L. Tsui, B. Chiu, H. W. O. Tsui, and R. D. Inman, "Serum cytokine receptors in ankylosing spondylitis: relationship to inflammatory markers and endoplasmic reticulum aminopeptidase polymorphisms," Journal of Rheumatology, vol. 37, no. 9, pp. 1907-1910, 2010.

[149] Y. Goto, K. Ogawa, A. Hattori, and M. Tsujimoto, "Secretion of endoplasmic reticulum aminopeptidase 1 is involved in the activation of macrophages induced by lipopolysaccharide and interferon- $\gamma$," Journal of Biological Chemistry, vol. 286, no. 24, pp. 21906-21914, 2011.

[150] M. A. Brown, "Progress in the genetics of ankylosing spondylitis," Briefings in Functional Genomics, vol. 10, no. 5, pp. 249-257, 2011.

[151] W. H. Fridman, C. Bonnerot, M. Daeron, S. Amigorena, J. L. Teillaud, and C. Sautes, "Structural bases of Fc $\gamma$ receptor functions," Immunological Reviews, vol. 125, pp. 49-76, 1992.

[152] A. Yada, S. Ebihara, K. Matsumura et al., "Accelerated antigen presentation and elicitation of humoral response in vivo by Fc $\gamma$ RIIB- and Fc $\gamma$ RI/III-mediated immune complex uptake," Cellular Immunology, vol. 225, no. 1, pp. 21-32, 2003.

[153] J. E. Gessner, H. Heiken, A. Tamm, and R. E. Schmidt, "The IgG Fc receptor family," Annals of Hematology, vol. 76, no. 6, pp. 231248, 1998.

[154] F. Nimmerjahn and J. V. Ravetch, "Fc $\gamma$ receptors as regulators of immune responses," Nature Reviews Immunology, vol. 8, no. 1, pp. 34-47, 2008.

[155] T. Takai, "Fc receptors and their role in immune regulation and autoimmunity," Journal of Clinical Immunology, vol. 25, no. 1, pp. 1-18, 2005.

[156] R. N. Stefanescu, M. Olferiev, Y. I. Liu, and L. Pricop, "Inhibitory Fc gamma receptors: from gene to disease," Journal of Clinical Immunology, vol. 24, no. 4, pp. 315-326, 2004.

[157] N. E. Phillips and D. C. Parker, "Fc-dependent inhibition of mouse B cell activation by whole anti- $\mu$ antibodies," Journal of Immunology, vol. 130, no. 2, pp. 602-606, 1983.

[158] N. R. Pritchard, A. J. Cutler, S. Uribe, S. J. Chadban, B. J. Morley, and K. G. C. Smith, "Autoimmune-prone mice share a promoter haplotype associated with reduced expression and function of the Fc receptor Fc $\gamma$ RII," Current Biology, vol. 10, no. 4, pp. 227$230,2000$.

[159] K. Su, X. Li, J. C. Edberg, J. Wu, P. Ferguson, and R. P. Kimberly, "A promoter haplotype of the immunoreceptor tyrosine-based inhibitory motif-bearing Fc $\gamma$ RIIb alters receptor expression and associates with autoimmunity. II. Differential binding of GATA4 and Yin-Yang1 transcription factors and correlated receptor expression and function," Journal of Immunology, vol. 172, no. 11, pp. 7192-7199, 2004.

[160] M. C. Blank, R. N. Stefanescu, E. Masuda et al., "Decreased transcription of the human FCGR2B gene mediated by the -343 G/C promoter polymorphism and association with systemic lupus erythematosus," Human Genetics, vol. 117, no. 2-3, pp. 220-227, 2005.

[161] Z. H. Duan, F. M. Pan, Z. Zeng et al., "The FCGR2B rs10917661 polymorphism may confer susceptibility to ankylosing spondylitis in Han Chinese: a casecontrol study," Scandinavian Journal of Rheumatology, vol. 41, no. 3, pp. 219-222, 2012.

[162] Ma. de Jesús Durán-Avelar, N. Vibanco-Pérez, A. N. RodríguezOcampo, J. M. Agraz-Cibrian, S. Peña-Virgen, and J. F. Zambrano-Zaragoza, "Humoral immune response to Salmonella sntigens and polymophisms in receptors for the $\mathrm{Fc}$ of $\mathrm{IgG}$ in patients with ankylosing spondylitis," in Clinical and Molecular Advances in Ankylosing Spondylitis, J. BrugesArmas, Ed., Intech, 2012, http://www.intechopen.com/books/ clinical-and-molecular-advances-in-ankylosing-spondylitis/ humoral-immune-response-to-salmonella-antigens-and-polymorphisms-in-receptors-for-the-fc-of-igg-in-p.

[163] J. F. Zambrano-Zaragoza, D. A. M. de Jesus, A. N. RodríguezOcampo et al., "The $30-\mathrm{kDa}$ band from Salmonella typhimurium: IgM, IgA and IgG antibody response in patients with ankylosing spondylitis," Rheumatology, vol. 48, no. 7, pp. 748 754, 2009.

[164] A. Hjelholt, T. Carlsen, B. Deleuran et al., "Increased levels of IgG antibodies against human HSP60 in patients with spondyloarthritis," PloS One, vol. 8, no. 2, Article ID e56210, 2013.

[165] M. J. Morales-Lara, P. Conesa-Zamora, M. S. Garca-Simón et al., "Association between the FCGR3A V158F polymorphism and the clinical response to infliximab in rheumatoid arthritis and spondyloarthritis patients," Scandinavian Journal of Rheumatology, vol. 39, no. 6, pp. 518-520, 2010.

[166] F. van Hauwermeiren, R. E. Vandenbroucke, and C. Libert, "Treatment of TNF mediated diseases by selective inhibition of soluble TNF or TNFR1," Cytokine and Growth Factor Reviews, vol. 22, no. 5-6, pp. 311-319, 2011.

[167] P. P. Tak and J. R. Kalden, "Advances in rheumatology: new targeted therapeutics," Arthritis Research and Therapy, vol. 13, no. 1, article S5, 2011.

[168] C. T. Chou, A. P. Huo, H. N. Chang, C. Y. Tsai, W. S. Chen, and H. P. Wang, "Cytokine production from peripheral blood mononuclear cells in patients with ankylosing spondylitis and their first-degree relatives," Archives of Medical Research, vol. 38, no. 2, pp. 190-195, 2007.

[169] D. Wendling and C. Prati, "Biologic agents for treating ankylosing spondylitis: beyond TNF $\alpha$ antagonists," Joint Bone Spine, vol. 78, no. 6, pp. 542-544, 2011.

[170] J. Braun, A. Deodhar, B. Dijkmans et al., "Efficacy and safety of infliximab in patients with ankylosing spondylitis over a twoyear period," Arthritis and Rheumatism, vol. 59, no. 9, pp. 12701278, 2008.

[171] D. van der Heijde, M. H. Schiff, J. Sieper et al., "Adalimumab effectiveness for the treatment of ankylosing spondylitis is maintained for up to 2 years: long-term results from the ATLAS trial," Annals of the Rheumatic Diseases, vol. 68, no. 6, pp. 922929, 2009. 
[172] I. Saougou, T. E. Markatseli, P. V. Voulgari, and A. A. Drosos, "Maintained clinical response of infliximab treatment in ankylosing spondylitis: a 6-year long-term study," Joint Bone Spine, vol. 77, no. 4, pp. 325-329, 2010.

[173] S. Arends, A. Spoorenberg, P. M. Houtman et al., "The effect of three years of TNF alpha blocking therapy on markers of bone turnover and their predictive value for treatment discontinuation in patients with ankylosing spondylitis: a prospective longitudinal observational cohort study," Arthritis Research \& Therapy, vol. 14, no. 2, article R98, 2012.

[174] K. Y. Kang, K. Y. Lee, S. K. Kwok et al., “The change of bone mineral density according to treatment agents in patients with ankylosing spondylitis," Joint Bone Spine, vol. 78, no. 2, pp. 188193, 2011.

[175] E. Gallo, T. Cabaleiro, M. Román, F. Abad-Santos, and E. Daudén, "Study of genetic polymorphisms in the tumor necrosis factor $\alpha$ promoter region in Spanish patients with psoriasis," Actas Dermo-Sifiliograficas, vol. 103, no. 4, pp. 301-307, 2012.

[176] N. Kothari, J. Bogra, H. Abbas et al., “Tumor Necrosis Factor gene polymorphism results in high TNF level in sepsis and septic shock," Cytokine, vol. 61, no. 2, pp. 676-681, 2013.

[177] A. G. Wilson, J. A. Symons, T. L. Mcdowell, H. O. Mcdevitt, and G. W. Duff, "Effects of a polymorphism in the human tumor necrosis factor $\alpha$ promoter on transcriptional activation," Proceedings of the National Academy of Sciences of the United States of America, vol. 94, no. 7, pp. 3195-3199, 1997.

[178] M. Seitz, U. Wirthmüller, B. Möller, and P. M. Villiger, "The -308 tumour necrosis factor- $\alpha$ gene polymorphism predicts therapeutic response to TNF $\alpha$-blockers in rheumatoid arthritis and spondyloarthritis patients," Rheumatology, vol. 46, no. 1, pp. 93-96, 2007.

[179] J. Zalevsky, T. Secher, S. A. Ezhevsky et al., "Dominant-negative inhibitors of soluble TNF attenuate experimental arthritis without suppressing innate immunity to infection," Journal of Immunology, vol. 179, no. 3, pp. 1872-1883, 2007.

[180] R. A. Black, C. T. Rauch, C. J. Kozlosky et al., "A metalloproteinase disintegrin that releases tumour-necrosis factor- $\emptyset$ from cells," Nature, vol. 385, no. 6618, pp. 729-733, 1997.

[181] X. Chen and J. J. Oppenheim, "Contrasting effects of TNF and anti-TNF on the activation of effector $\mathrm{T}$ cells and regulatory $\mathrm{T}$ cells in autoimmunity," FEBS Letters, vol. 585, no. 23, pp. 36113618, 2011.

[182] M. Grell, E. Douni, H. Wajant et al., “The transmembrane form of tumor necrosis factor is the prime activating ligand of the 80 $\mathrm{kDa}$ tumor necrosis factor receptor," Cell, vol. 83, no. 5, pp. 793802, 1995.

[183] G. Chen and D. V. Goeddel, “TNF-R1 signaling: a beautiful pathway," Science, vol. 296, no. 5573, pp. 1634-1635, 2002.

[184] J. Cuenca, M. Cuchacovich, C. Pérez et al., "The -308 polymorphism in the tumour necrosis factor (TNF) gene promoter region and ex vivo lipopolysaccharide-induced TNF expression and cytotoxic activity in Chilean patients with rheumatoid arthritis," Rheumatology, vol. 42, no. 2, pp. 308-313, 2003.

[185] X. Chen, X. Wu, Q. Zhou, O. M. Howard, M. G. Netea, and J. J. Oppenheim, "TNFR2 is critical for the stabilization of the CD4+Foxp3+ regulatory T. cell phenotype in the inflammatory environment," Journal of Immunology, vol. 190, no. 3, pp. 10761084, 2013.

[186] F. S. Kleijwegt, S. Laban, G. Duinkerken et al., "Critical role for TNF in the induction of human antigen-specific regulatory $\mathrm{T}$ cells by tolerogenic dendritic cells," Journal of Immunology, vol. 185, no. 3, pp. 1412-1418, 2010.
[187] E. G. Corona-Sanchez, J. F. Muñoz-Valle, L. Gonzalez-Lopez et al., "-383 A/C tumor necrosis factor receptor 1 polymorphism and ankylosing spondylitis in Mexicans: a preliminary study," Rheumatology International, vol. 32, no. 8, pp. 2565-2568, 2012. 


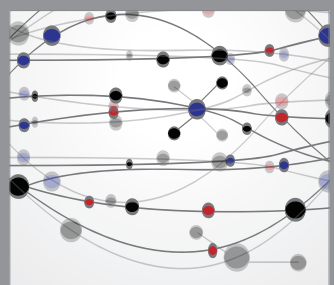

The Scientific World Journal
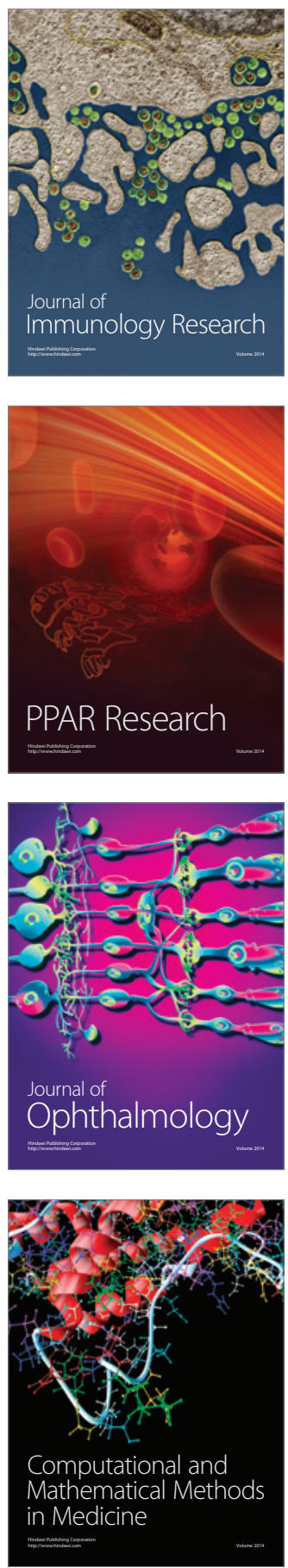

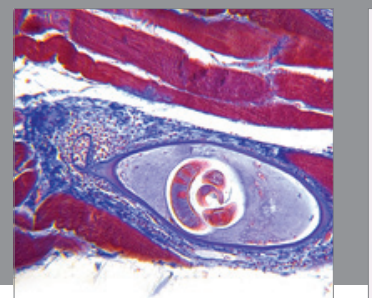

Gastroenterology

Research and Practice
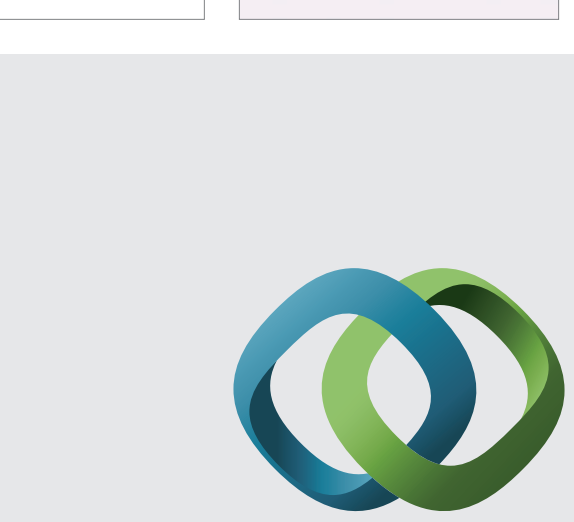

\section{Hindawi}

Submit your manuscripts at

http://www.hindawi.com
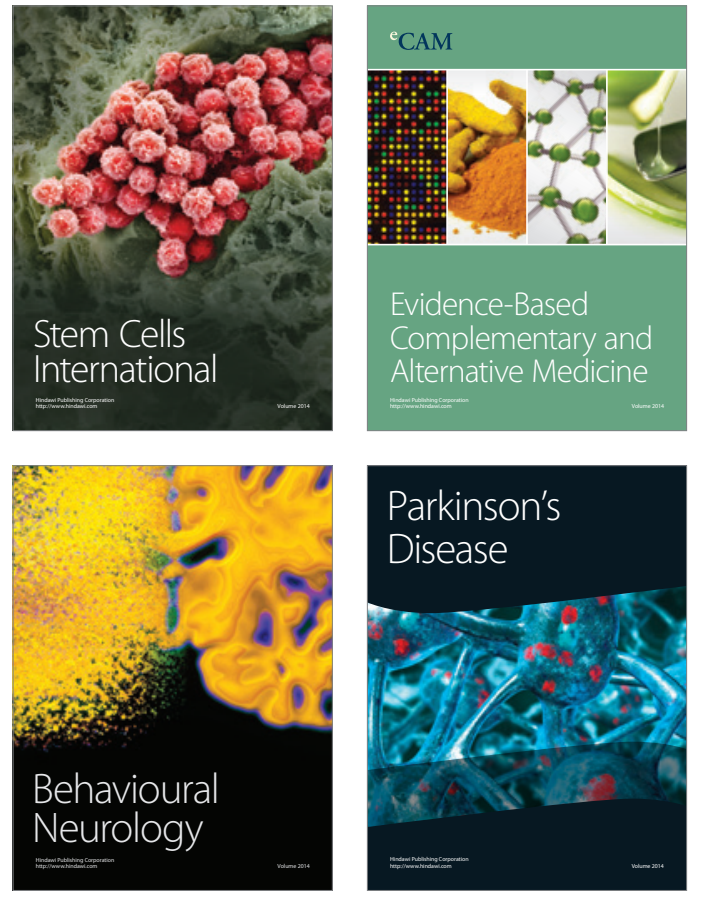
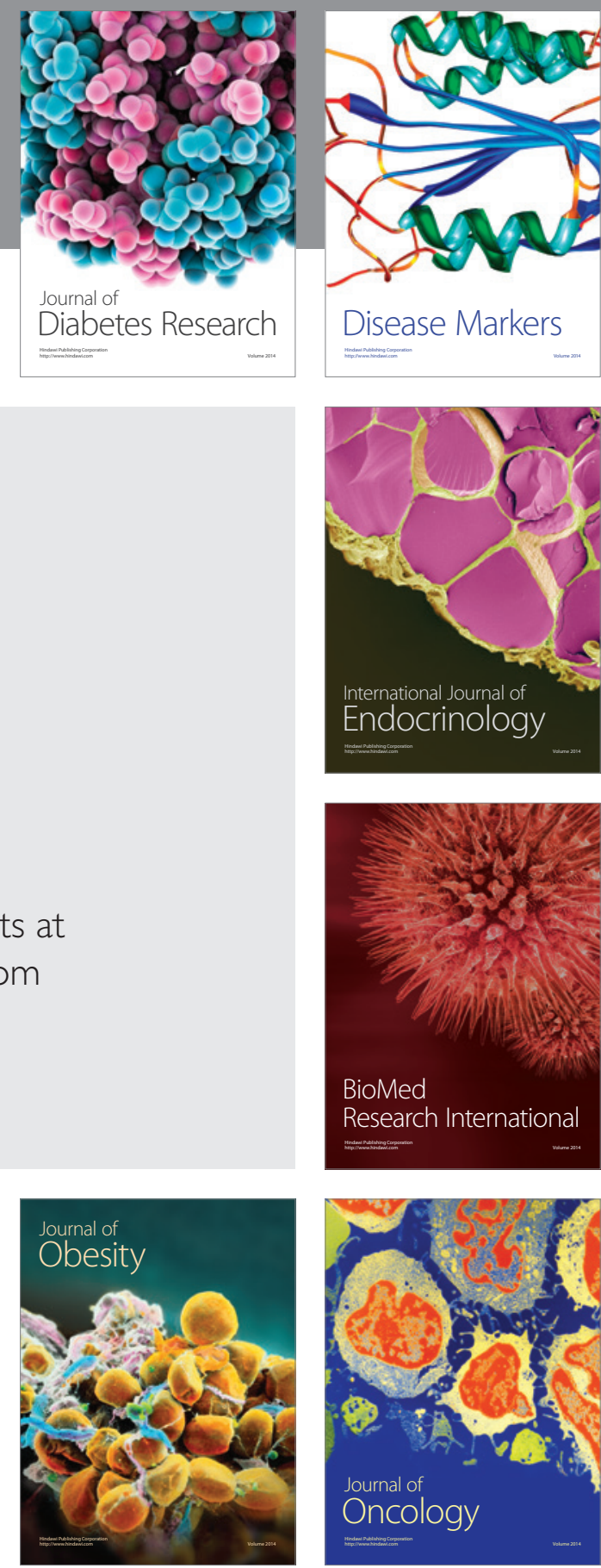

Disease Markers
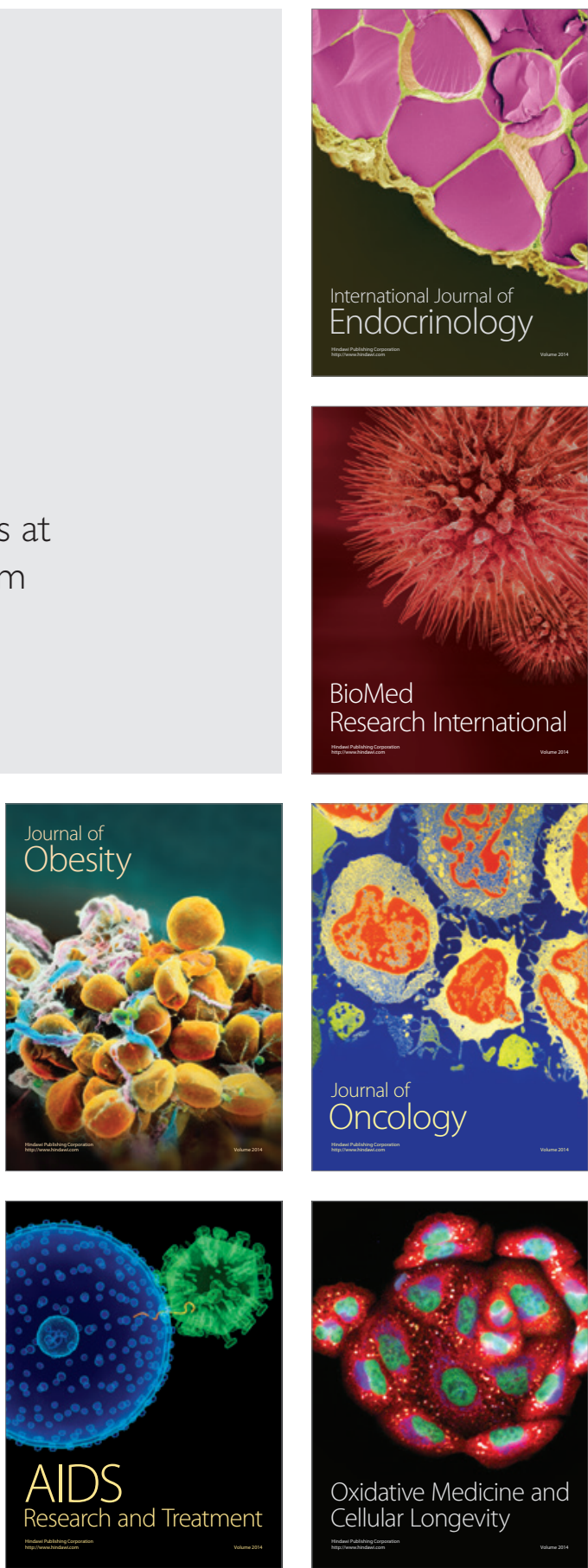